FEDERAL RESERVE BANK OF SAN FRANCISCO

WORKING PAPER SERIES

\title{
Government employment expenditure and the effects of fiscal policy shocks
}

\author{
Michele Cavallo \\ Federal Reserve Bank of San Francisco
}

September 2005

Working Paper 2005-16

http://www.frbsf.org/publications/economics/papers/2005/wp05-16bk.pdf

The views in this paper are solely the responsibility of the authors and should not be interpreted as reflecting the views of the Federal Reserve Bank of San Francisco or the Board of Governors of the Federal Reserve System. 


\begin{abstract}
Since World War II, about 75 percent of consumption expenditure by the U.S. government has consisted of wages and salaries for government employees. I distinguish between the goods and the employment expenditure components of government consumption in assessing the effects of fiscal shocks on the macroeconomy. Identifying exogenous fiscal shocks with the onset of military buildups, I show that they lead to a substantial increase in both the number of hours worked and output for the government. I also show that allowing for the distinction between the two main components of government consumption improves the quantitative performance of the neoclassical growth model. In particular, a neoclassical model economy with government employment does a good job of accounting for the dynamic response of private consumption to a fiscal policy shock. Government employment expenditure acts as a transfer payment for households, thereby dampening substantially the wealth effect on consumption and labor supply associated with fiscal shocks.
\end{abstract}

KEYWORDS: Government employment; Fiscal policy

JEL ClASSIFICATION CODES: E20; E24; E32; E62; H30

I thank Mark Gertler, Fabrizio Perri and Nouriel Roubini for advice, Silvia Ardagna for her thoughtful discussion, Charlie Gilbert for help with data, Judith Goff and Anita Todd for editorial assistance, Gregory Snyders and Thien Nguyen for excellent research assistance, and seminar participants at Bank of England, Erasmus Universiteit, Federal Reserve Bank of Boston, Federal Reserve Bank of San Francisco, Federal Reserve Board, New York University, Sveriges Riksbank, University of British Columbia, University of Maryland, SED 2003 Annual Meeting, and at 2005 North American Winter Meeting of the Econometric Society for useful comments. I also benefited from helpful conversations with Shaghil Ahmed, Stefania Albanesi, George Alessandria, Pierpaolo Benigno, David Bowman, Xiaohong Chen, Martin Eichenbaum, Stefano Eusepi, Jon Faust, John Fernald, Michael Feroli, Jonas Fisher, Charles Fleischman, Jeffrey Fuhrer, Jordi Galí, Dale Henderson, Òscar Jordà, Boyan Jovanovic, Andy Levin, Sydney Ludvigson, Fabio Natalucci, Giorgio Primiceri, Vincenzo Quadrini, Pau Rabanal, John Rogers, Daniele Terlizzese, Bharat Trehan, Gianluca Violante, Karl Wheelan, and John Williams. I started this project during my internship in the Division of International Finance at the Federal Reserve Board. I owe my gratitude to its members for their stimulating hospitality. All remaining errors are my own. The views in this paper are solely my responsibility and should not be interpreted as reflecting the views of the Federal Reserve Bank of San Francisco, or the Federal Reserve System. 


\section{Introduction}

Wages and salaries account for a large share of consumption expenditure on goods and services by the U.S. government. During the post World War II period, government wage and salary expenditure has accounted, on average, for about 75 percent of government consumption, and for about 63 percent of government expenditure on consumption and investment. However, much of the literature that focuses on the effects of fiscal policy shocks treats government consumption as consisting entirely of expenditure on goods, overlooking the wage and salary component.

In this paper, I study the effects of fiscal policy shocks on main macroeconomic variables. In particular, I evaluate the ability of the neoclassical growth model to account for these effects. For one crucial element of fiscal policy, government consumption expenditure on goods and services, I distinguish between expenditure on goods and expenditure on wages and salaries, which, essentially, corresponds to expenditure on hours. This distinction is important because shocks to these two components lead to very different macroeconomic effects. In a neoclassical model economy, in fact, an unanticipated increase in government expenditure on goods represents a resource drain for households. As such, it entails a substantial negative wealth effect that leads to a negative impact on private consumption and a positive impact on both the number of hours worked and output in the private sector. In contrast, an unanticipated increase in government expenditure on hours has a negative impact on the number of hours worked and output in the private sector, but, essentially, it does not generate a negative wealth effect on private consumption and total labor supply. The reason for these different effects is that government wages and salaries represent income for households and, as such, act essentially as transfers.

Therefore, taking into explicit account the composition of government consumption on goods and services and, in particular, the role of its employment expenditure component ensures that the policy experiment studied in the model economy corresponds more closely with the policy episodes 
identified in the data. This is relevant for assessing the ability of a neoclassical model economy to explain the macroeconomic effects of fiscal policy shocks. In fact, it allows a relatively more accurate comparison of the model's response to a fiscal policy shock with the outcome of the corresponding policy episodes in the actual data.

Following Ramey and Shapiro (1998), I identify exogenous fiscal policy shocks with the onset of military buildups. Ramey and Shapiro (1998), using a narrative approach, isolated three episodes of military buildups that were associated with exogenous, large, and persistent increases in the national defense component of government consumption expenditure. Besides Ramey and Shapiro (1998), this paper is related to the work of Burnside, Eichenbaum and Fisher (2004). In particular, it extends their analysis by including government hours in the set of exogenous fiscal policy variables. To assess the role played by this additional variable, I derive a new quarterly series for the number of hours worked in the government sector, and I compute its corresponding estimated response to an identified exogenous fiscal policy shock.

To understand how the inclusion of government employment affects the ability of the neoclassical growth model to account for the effects of fiscal policy shocks, I set up a model economy that distinguishes between government expenditure on goods and government expenditure on hours, in line with the work of Finn (1998). ${ }^{1}$ For consistency with aggregate NIPA data, I allow for government production, and I assume that the government combines hours and a fraction of its goods purchases to assemble what I refer to as government output. ${ }^{2}$ Following Jones (2002) and Burnside, Eichenbaum and Fisher (2004), I consider distortionary taxation on labor and capital

\footnotetext{
${ }^{1}$ Models that allow for the distinction between government expenditure on goods and government expenditure on wages and salaries also include those by Rotemberg and Woodford (1992), Ardagna (2001), and McGrattan and Ohanian (2003). In contrast, the works by Baxter and King (1993) and Ohanian (1997) distinguish between government consumption expenditure on goods and services and government investment expenditure.

${ }^{2}$ In the National Income and Product Accounts (NIPA), government output corresponds to the sum of compensation of government employees and government consumption of fixed capital. In turn, government consumption of fixed capital represents a fraction of government consumption expenditure of goods and services.
} 
income. ${ }^{3}$ To evaluate the quantitative performance of the neoclassical model economy, I compare the macroeconomic variables' simulated responses obtained from the model with their empirical counterparts estimated from the actual data. To obtain the simulated responses, I feed into a linearized version of the model economy the estimated responses of the four fiscal policy variables. These variables are: government expenditure on goods, government hours, labor tax rates, and capital tax rates.

I evaluate the performance of three versions of the neoclassical model. First, I consider a version called the standard model, where government consumption expenditure consists entirely of expenditure on final goods and where government employment is not taken into consideration. In line with the findings of much of the literature, I find that the standard model can account for the qualitative effects of fiscal policy shock but not for the quantitative effect. In particular, the simulated responses of private consumption and investment are significantly larger, in absolute value, than their estimated counterparts. ${ }^{4}$

Second, I consider a version called the government employment model, in which only government hours react to the exogenous fiscal policy shock. The counterfactual policy experiment in this version helps clarify the dynamic effects of a fiscal shock to government employment only. In line with what is shown by Finn (1998), I find that hours, output, and investment in the private sector decrease in response to an unanticipated increase in government hours. Essentially, no wealth effect is associated with a fiscal shock to government expenditure on hours, as this type of expenditure, basically, acts as a transfer for households.

Last, I consider a version called the modified model where all four fiscal policy variables react to the exogenous fiscal shock, hence allowing government employment to play a significant role.

\footnotetext{
${ }^{3}$ Among others, models with distortionary taxation that study the effects of fiscal shocks include those of Braun (1994), Dotsey (1994), Campbell (1994), McGrattan (1994), Ohanian (1997), Fatás and Mihov (2001), and, more recently, that of Basu and Kimball (2004).

${ }^{4}$ This result confirms the findings of Burnside, Eichenbaum and Fisher (2004).
} 
This is the most realistic of the three versions that I consider. In fact, the distinction between the two main components of government consumption allows to reproduce more closely within a neoclassical model economy the policy episodes identified in the actual data. I find that government employment expenditure, by acting as a transfer for households, substantially dampens the negative wealth effect on consumption and labor supply associated with fiscal policy shocks. This allows the simulated response of private consumption to come significantly close to its estimated counterpart. The evidence provided in Ramey and Shapiro (1998), Edelberg, Eichenbaum, and Fisher (1999), and Burnside, Eichenbaum and Fisher (2004), as well as in this paper, shows that private consumption is only barely decreasing after the onset of a military buildup. This piece of evidence provides support for a model economy where wealth effects associated with fiscal policy shocks are quantitatively less important.

Overall, this paper suggests that the quantitative shortcomings of the neoclassical model in accounting for the effects of fiscal policy shocks are likely due to its considering government consumption as consisting entirely of expenditure on goods. ${ }^{5}$ In fact, this paper shows that allowing for government employment expenditure improves the match between the estimated responses of macroeconomic variables to a fiscal shock and the corresponding model responses. In particular, a novel result here is that the neoclassical model, augmented with the inclusion of government employment, does a good job of accounting for the estimated responses of private consumption and investment to an exogenous fiscal policy shock.

The rest of the paper is organized as follows. Section 2 presents the empirical evidence on the effects of fiscal policy shocks. Section 3 describes the model economy. Section 4 presents the numerical values assigned to the parameters of the model economy. Section 5 discusses the performance of the model by comparing the simulated model responses of the macroeconomic variables to a fiscal

\footnotetext{
${ }^{5}$ See, for example, Aiyagari, Christiano and Eichenbaum (1992), Christiano and Eichenbuam (1992), Baxter and King (1993), and Campbell (1994).
} 
policy shock with their estimated counterparts. Section 6 concludes.

\section{Empirical evidence on the effects of fiscal policy shocks}

In this section, I present the empirical evidence regarding the effects of fiscal policy shocks. Following Ramey and Shapiro (1998), I identify fiscal policy shocks with the onset of military buildups. Using a narrative approach for the identification of exogenous fiscal policy shocks, Ramey and Shapiro (1998) isolated three dates for the beginning of military buildups: 1950:Q3 for the Korean war, 1965:Q1 for the Vietnam war, and 1980:Q1 for the Carter-Reagan buildup. These dates are associated with large increases in defense expenditure, as shown in Figure 1. Military buildups and, more generally, changes in the national defense component of government expenditure represent an effective laboratory for studying the aggregate effects of fiscal policy shocks. ${ }^{6}$ They offer two main advantages. First, being driven by geopolitical considerations, they are likely to be exogenous with respect to the macroeconomic environment. Second, they are less likely to substitute for private consumption or to affect private technology. In this respect, they can be modeled easily as "basic" government consumption, defined as that absorbing resources without directly affecting private consumption decisions or private production. As evident from Figure 2, Ramey-Shapiro episodes are also associated with a significant increase in total government consumption and in labor and capital tax rates.

In Figure 3, I plot different measures of government employment. Two of the three RameyShapiro dates are associated with substantial increases in defense and total government employment. This piece of evidence provides the ground for separating the employment compensation component from the goods component of government consumption, and for including hours worked for the

\footnotetext{
${ }^{6}$ Others studies that adopt the narrative approach for the identification of exogenous fiscal policy shocks are Edelberg, Eichenbaum and Fisher (1999), Burnside, Eichenbaum and Fisher (2004) and Eichenbaum and Fisher (2005). For alternative identification approaches see Rotemberg and Woodford (1992), Fatás and Mihov (2001), Alesina, Ardagna, Perotti and Schiantarelli (2002), Blanchard and Perotti (2002), Mountford and Uhlig (2002), Galí, López-Salido, and Vallés (2005), and Perotti (2005).
} 
government in the set of fiscal policy variables that respond to the onset of a Ramey-Shapiro episode.

I estimate the impact of a military buildup on a set of macroeconomic variables. These variables are: real GDP, real private consumption, real investment, real private output, real government output, total hours, private hours, after-tax real compensation, real government consumption expenditure on goods and services minus compensation of employees, government hours, labor tax rates, and capital tax rates. I employ quarterly data. The sample period is 1948:Q1 - 2000:Q4. Appendix A2. describes the data used in my analysis.

As for tax rates on labor and capital income, I obtain them following the method of Jones (2002), as extended by Burnside, Eichenbaum and Fisher (2004).

I also construct a new quarterly series for the number of hours worked in the government sector. NIPA tables provide a series at annual frequency for government hours. I obtain the quarterly series by using an interpolation method. Specifically, I use the approach of Chow and Lin (1971), and, as interpolators, I employ the quarterly series for compensation of general government employees and for the number of employees that work for the government. Once I interpolate the quarterly series, in order to check its validity, I turn it into an annual series and I compute its correlation with the original series of government hours. The correlation coefficient is $0.9973 .^{7}$

As in Ramey and Shapiro (1998), I denote by $D_{t}$ the dummy variable representing the onset of a military buildup, where $D_{t}=1$ if $t=\{1950: \mathrm{Q} 3$, 1965:Q1, 1980:Q1 $\}$, and zero otherwise. I estimate by ordinary least squares the parameters of the following equation:

$$
z_{t}=a_{0}+a_{1} t+a_{2}(t \geq 1973: \mathrm{Q} 2)+\sum_{i=1}^{8} b_{i} z_{t-i}+\sum_{i=0}^{8} c_{i} D_{t-1}+u_{t},
$$

where $z_{t}$ is the variable whose impulse response I am interested in studying, $t$ is a time trend starting at the beginning of the sample period, i.e., in 1948:Q1, $(t \geq 1973:$ Q2) is another time trend that

\footnotetext{
${ }^{7}$ Francis and Ramey (2005) also derive a series for government hours.
} 
begins in the second quarter of 1973 , and $u_{t}$ is a zero-mean disturbance term. As in Ramey and Shapiro (1998), I included a trend break term in the estimating equation (1) to nest both the hypothesis of unit roots and deterministic trends for all the variables of interest. The parameters $a_{0}, a_{1}, a_{2}, b_{i}$ and $c_{i}$ are the coefficients to be estimated. Except for tax rates, all variables are in logarithms.

To obtain estimates for the dynamic effects of an exogenous fiscal policy shock, which corresponds to the onset of a Ramey-Shapiro episode, I estimate equation (1) for each of the variables that I consider. To derive the estimated impulse response function of $z_{t}$ to the onset of a military buildup, I simulate the estimated version of (1) in response to the dummy variable $D_{t}$ assuming the value of one. I report the graphs of the estimated impulse responses in Figures 4 and $5 .{ }^{8}$

First, I analyze the estimated responses of fiscal policy variables, as illustrated in Figure 4. Military buildups lead to a large and significant increase in government consumption expenditure on goods and in government hours. Expenditure on goods increases strongly. It peaks after two and one-half years at almost 21 percent above its preshock level (panel A). Government hours peak at 5.5 percent above trend after almost two years (panel B). Tax rates also react positively to the onset of a Ramey-Shapiro episode (panels C and D). Labor tax rates increase by 1.25 percent after almost two years, while the reaction of capital tax rates is quantitatively stronger and less smooth than the reaction of labor tax rates. It increases by 3.6 percent after three quarters and then returns

\footnotetext{
${ }^{8}$ In Figures 4 and 5, solid lines represent point estimates, while dashed lines delimit a 95 percent confidence interval for the point estimates of the impulse responses. I computed the confidence intervals following the bootstrap Monte Carlo procedure used by Edelberg, Eichenbaum and Fisher (1999). Specifically, with $T$ being the length of the sample period that I consider in the empirical analysis, I computed 500 artificial time series of length $T$ on the variable $z_{t}$ as follows. I constructed 500 new time series of residuals $\left\{\hat{u}_{t}(j)\right\}_{t=1}^{T}, j=1, \ldots, 500$, by drawing randomly with replacement from the vector of fitted residuals $\left\{\hat{u}_{t}\right\}_{t=1}^{T}$ from equation (1). For each constructed series of new residuals, I computed an artificial time series $\left\{\hat{z}_{t}(j)\right\}_{t=1}^{T}, j=1, \ldots, 500$, using the estimated equation and the historical initial conditions on $z_{t}$. I then reestimated equation (1) using $\left\{\hat{z}_{t}(j)\right\}_{t=1}^{T}$ and I calculated the implied impulse response function for $j=1, \ldots, 500$. For each fixed lag, I computed the $12^{\text {th }}$ lowest and the $487^{\text {th }}$ highest values of the corresponding impulse response coefficients across all 500 artificial impulse response functions. The boundaries of confidence intervals in the figures correspond to a graph of these coefficients. The point estimates of the impulse responses are similar to the average value of the artificial impulse responses.
} 
rapidly to its preshock level.

First, I analyze the estimated responses of the main macroeconomic variables, as illustrated in Figure 5. As for these responses, similar estimated responses appear in Ramey and Shapiro (1998), Edelberg, Eichenbaum and Fisher (1999), and Burnside, Eichenbaum and Fisher (2004). Total output and private output increase above trend by more than 3 percent after five quarters (panels A and B). Their dynamic behavior is both qualitatively and quantitatively similar. The increase in total output is significantly different from zero only at impact and after five quarters at its peak response. Government output reacts sharply to a military buildup (panel C). It reaches a peak response of 7.75 percent above trend after two years and then converges back to its preshock level. Total hours and private hours peak at 1.8 and 1.3 percent, respectively, after almost two years, but the estimates of their responses are not significantly different from zero (panels D and E). Investment expenditure peaks slightly above 2 percent over its preshock level after five quarters and then slowly reverts back to trend (panel F). Its response is significantly different from zero on impact and from quarter five to quarter seven after the shock. As for the response of after-tax real compensation in the business sector, its response to a military buildup is negative and significantly different from zero for a large number of periods, from quarter three until quarter eighteen (panel G). Its largest response is a decline of about 3.6 percent after two years. Personal consumption expenditure on nondurables and services reacts negatively to a fiscal shock (panel $\mathrm{H}$ ). This qualitative response is in line with the predictions of the neoclassical model about the response of consumption to a government spending shock. The reaction is significantly different from zero only in the second period after the impact of the shock. The peak response is a decrease of about 1.33 percent one period after the shock. 


\section{$3 \quad$ The model economy}

This section describes the neoclassical model economy, augmented for the inclusion of government employment, as in Finn (1998). The model economy includes a household sector, a private sector, and government. There are a large number of identical households, and a large number of firms in the private sector, all of whom are infinitely lived. Time is divided into periods and each period is indexed by the subscript $t$.

Households consume final goods and supply labor to firms in the private sector and to the government. They have preferences over consumption of goods, $C_{t}$, and the number of hours they work, $n_{t}$, which represents labor supply. These preferences are described by the following utility function:

$$
E_{t} \sum_{i=0}^{\infty} \beta^{i}\left[\log C_{t+i}+\frac{\theta}{1-\mu}\left(1-n_{t}\right)^{1-\mu}\right], \quad \mu \geq 0
$$

where $E_{t}$ is the time $t$ conditional expectation operator and $\beta$ is the subjective discount factor. The preferences in (2) imply a steady-state compensated labor supply elasticity of $\mu n /(1-n)$. Households own the the capital stock, whose value at the beginning of period $t$ is $k_{t}$, and choose the level of investment expenditure, $I_{t}$, incurring investment adjustment costs. The capital stock evolves according to the following law of motion:

$$
k_{t+1}=(1-\delta) k_{t}+F\left(I_{t}, I_{t-1}\right), \quad 0<\delta<1,
$$

where $\delta$ is the depreciation rate and where

$$
F\left(I_{t}, I_{t-1}\right)=\left[1-S\left(\frac{I_{t}}{I_{t-1}}\right)\right] I_{t}
$$

Christiano, Eichenbaum and Evans (2005) argue that hump-shaped responses of investment to shocks are a natural outcome with the specification as in (4). In addition, with such a specification of the adjustment cost function, Burnside, Eichenbaum, and Fisher (2004) obtain a sympathetic 
response of hours worked to a fiscal shock. The function $S(\cdot)$ has the property that, in the nonstochastic steady state, $S(\cdot)=S^{\prime}(\cdot)=0$, and $s=S^{\prime \prime}(\cdot)>0$. Then $F_{1}(\cdot, \cdot)=1$, and $F_{2}(\cdot, \cdot)=0$.

Household rent capital and supply labor in perfectly competitive factor markets. The real wage is $W_{t}$ and the rental rate of capital is $R_{t}^{k}$. Household also pays lump-sum taxes, $T_{t}$, and proportional taxes on their labor income and on their capital income net of depreciation. The tax rates are $\tau_{t}^{n}$ and $\tau_{t}^{k}$, respectively. The budget constraint for households is:

$$
C_{t}+I_{t}=\left(1-\tau_{t}^{n}\right) W_{t} n_{t}+\left(1-\tau_{t}^{k}\right) R_{t}^{k} k_{t}+\delta \tau_{t}^{k} k_{t}-T_{t}
$$

Firms in the private sector produce $Y_{t}^{P}$ using labor and capital supplied from households. Their production function is:

$$
Y_{t}^{P}=\left(A_{t} N_{t}^{P}\right)^{\alpha} K_{t}^{1-\alpha}, \quad 0<\alpha<1
$$

where $A_{t}$ represents a measure of the level of technology, $N_{t}^{P}$ is the number of hours supplied from households to private-sector firms, and $K_{t}$ is the capital stock in the economy as of the beginning of period $t$ rented by private-sector firms from households. Since firms in the private sector act in a perfectly competitive environment, the real wage and the rental rate of capital are equal to the marginal products of labor and capital, respectively. The growth rate of the level of technology is $(1+a) \cdot 9$

The government purchases goods, $G_{t}$, hires labor from households, $N_{t}^{G}$, and collects both proportional and lump-sum taxes from them. It uses a fraction $\phi$ of its purchases of goods in combination with the labor hired from households to produce government output, $Y_{t}^{G}$, according to the following production function:

$$
Y_{t}^{G}=\left(A_{t} N_{t}^{G}\right)^{\gamma} Z_{t}^{1-\gamma}, \quad 0<\gamma<1
$$

\footnotetext{
${ }^{9}$ This way of introducing growth is inconsistent with the way I consider growth in Section 2, where I assume a trend break in 1973:Q2. As in Burnside, Eichenbaum and Fisher (2004), when I solve for the competitive equilibrium, I approximate the introduction of a second trend term by linearizing the solution of the competitive equilibrium around the steady state of the model economy assuming a growth rate of output equal to the average growth rate of output over the whole sample period.
} 
where $Z_{t}$ denotes the amount of goods purchased by the government that are used in the production of government output: ${ }^{10}$

$$
Z_{t}=\phi G_{t}, \quad 0<\phi<1
$$

The parameter $\phi$, therefore, represents the share of productive goods expenditure by the government. Government expenditure on goods, and lump-sum taxes evolve according to

$$
G_{t}=A_{t} g_{t}, \quad T_{t}=A_{t} t_{t}
$$

where $g_{t}$ and $t_{t}$ represent the stationary components of government expenditure on goods and lumpsum taxes, respectively. The budget constraint of the government is

$$
G_{t}+W_{t} N_{t}^{G}=\tau_{t}^{k} R_{t} k_{t}+\tau_{t}^{n} W_{t} n_{t}-\delta \tau_{t}^{k} k_{t}+T_{t}+Y_{t}^{G}
$$

The real wage paid by the government to households is the same that households receive by supplying labor to private-sector firms. This property follows from two assumptions. The first assumption is that $N_{t}^{P}$ and $N_{t}^{G}$ enter the utility function in a perfectly substitutable manner, hence working for the private sector or for the government brings households the same marginal disutility. The second assumption is that hours can be costlessly moved across sectors. Government lump-sum taxes, $T_{t}$, are determined in a residual way, so that the government budget is balanced every period. There are four exogenous fiscal policy variables: government expenditure on goods, government hours, labor tax rates, and capital tax rates. These variables are taken as given by households and firms. Following Burnside, Eichenbaum and Fisher (2004), I describe fiscal policy in terms of the vector $f_{t}=\left[\log G_{t}, \log N_{t}^{G}, \tau_{t}^{n}, \tau_{t}^{k}\right]^{\prime}$. This vector evolves according to (11) $f_{t}=f+h_{f}(L) \varepsilon_{t}$.

$f$ denotes the steady state value of $f_{t}, h_{f}$ is equal to $\left[h_{G}(L), h_{N^{G}}(L), h_{\tau^{n}}(L), h_{\tau^{k}}(L)\right]^{\prime}$, where each $h(L)$ is an ordered polynomial in nonnegative powers of the lag operator $L$, and $\varepsilon_{t}$ is a zero mean, 
i.i.d. scalar random variable which is orthogonal to all the variables in the model dated $t-1$ and earlier.

Finally, total output, $Y_{t}$, which represents total GDP, is the sum of output in the private sector and government output:

$$
Y_{t}=Y_{t}^{P}+Y_{t}^{G}
$$

A competitive equilibrium for this economy is a collection of allocations for the representative household, $C_{t}, N_{t}, I_{t}$, and $k_{t}$, for private goods firms, $N_{t}^{P}$ and $K_{t}$, and sequences of prices $W_{t}$ and $R_{t}^{K}$ such that: (i) taking prices, tax rates, $\tau_{t}^{n}$, and $\tau_{t}^{k}$, and lump-sum taxes, $T_{t}$, as given, households maximize (2) subject to (3), (4) and (5); (ii) taking prices as given, firms maximize profits period by period; and (iii) all factor and goods markets clear:

$$
\begin{aligned}
& k_{t}=K_{t}^{P}, \\
& n_{t}=N_{t}^{P}+N_{t}^{G}, \\
& C_{t}+I_{t}+G_{t}+W_{t} N_{t}^{G}=Y_{t} .
\end{aligned}
$$

Equation (15) is the aggregate resource constraint for the economy. It can be obtained by integrating the budget constraint for households (5) and for the government (10), and using the prices of the competitive equilibrium and the market clearing conditions.

I log-linearize the equations that define the competitive equilibrium around the nonstochastic steady state of the model. Then I solve the resulting system of linear difference equations applying the procedure of Anderson and Moore (1985). Appendix A1 gives the details of the steady state and of the log-linear system. 


\section{Parameter values}

This section presents the numerical values assigned to the parameters of the linearized model economy. The model period is one quarter. The baseline parametrization that I use follows that from Burnside, Eichenbaum and Fisher (2004). I set the subjective discount rate $\beta$ equal to $1.03^{-1 / 4}$, and the growth rate of output $a$ to 2 percent, the average growth rate of per capita output during the sample period. The capital share $\alpha$ is equal to 0.34 and the depreciation rate $\delta$ to 0.021 . The fraction of time endowment that households spends working, $N$, is equal to 0.24 . I set the parameter $\mu$ in the household's utility function equal to 1 and the adjustment cost parameter $s$ equal to 2 .

For the parameters relative to fiscal policy variables, I choose their steady-state values equal to the average values of their data counterparts for the whole sample period that I consider in the empirical analysis of Section 2. Whenever one of these average values for the sample period is different from the corresponding average value at the onset of the Ramey-Shapiro episodes, I choose the latter. I set the steady-state capital tax rate and labor tax rate $\tau^{k}$ and $\tau^{n}$ to 0.4 and 0.2 , respectively.

I consider three versions of the model. First, I consider a version of the model where all government consumption expenditure on goods and services is on goods. I refer to this version as the standard model, to mark its consistency with the way much of the literature has treated government consumption. In this version, I set the steady-state ratio of government consumption to GDP equal to 0.2 , which is the ratio of government consumption to GDP at the onset of the three Ramey-Shapiro episodes. I set the steady-state ratios of hours worked for the government to total hours and of government output to GDP equal to zero. In addition, the specification for the $j^{\text {th }}$ coefficient in the expansion of $h_{G}(L)$ is the estimated response of real total government consumption of goods and services at $t+j$ to the onset of a military buildup, where real government consumption represents total government consumption without the distinction between its main components. In 
this version, therefore, $h_{N^{G}}(L)$ is set equal to zero. The coefficients in the expansions of $h_{\tau^{n}}(L)$ and $h_{\tau^{k}}(L)$ are given by the estimated response of labor tax rates and capital tax rates. I use 48 coefficients in $h_{1}(L)$ and 24 coefficients in $h_{\tau^{n}}(L)$ and $h_{\tau^{k}}(L)$.

Second, I consider a version in which all of government consumption expenditure is just employment compensation. For simplicity, I call this version the government employment model. This second version helps understand the dynamic effects of a fiscal shock that leads to an increase in government employment only. In this version, the steady-state ratio of government expenditure on goods to GDP is zero. The steady-state ratio of government hours to total hours is 0.16 , which is the average ratio of these variables in the data, both for the sample period, and at the onset of the military buildups. I set the steady-state ratio of government output to total output to 0.17 . In this version, the $j^{\text {th }}$ coefficient in the expansion of $h_{N^{G}}(L)$ is given by the estimated response of hours worked for the government sector at $t+j$ to the onset of a military buildup. $h_{G}(L), h_{\tau^{n}}(L)$ and $h_{\tau^{k}}(L)$ are set to zero. I use 48 coefficients in $h_{N^{G}}(L)$.

While the first two versions of the model economy help understand the dynamic effects of a fiscal shock to government consumption of goods only and to government employment only, their degree of realism is limited. This is because fiscal policy shocks lead to significant increases in both components of government consumption, as clearly illustrated in Figure 4. Therefore, I consider a third version of the model in which both government consumption of goods and government hours respond to the fiscal shock, represented by the onset of a military buildup. I call this version the modified model. The idea is to have the model economy undergo the policy experiment that most closely corresponds to the policy episodes identified in the data. In this version of the model, I set the steady-state ratio of government consumption of goods to GDP equal to 0.05, and the share $\phi$ of productive government goods consumption to 0.11 . Finally, in the production function (7) for government output, I pick the parameter $\gamma$ by referring to the share of government wages in 
government output. Therefore, I set this parameter equal to the sample average of the ratio of government employment compensation to government output, which is 0.89 .

\section{Quantitative results}

In this section, I study the dynamic responses of the various macroeconomic variables in the three versions of the model economy to a fiscal policy shock that corresponds to the onset of a military buildup. To this purpose, I feed into the linearized version of the model economy the estimated response of the fiscal policy variables to the shock, and I compare the implied dynamic responses of variables in the model with their empirical counterparts estimated from the actual data. Starting from the nonstochastic steady state, I subject the model economy to a sequence of changes in government consumption of goods, government hours, and labor and capital tax rates corresponding to the point estimates of the changes in these variables after the onset of a RameyShapiro episode. I treat the initial shock as unexpected. Once it occurs, agents know what the paths of fiscal policy variables are going to be. I set the initial shock to unity, consistent with the way the policy experiment has been isolated in the empirical analysis of Section 5, where I estimated the dynamic responses of the macroeconomic variables to the dummy variable assuming a value of unity.

First, I consider the the standard model, in which government consumption expenditure consists entirely of expenditure on goods. Figure 6 illustrates the simulated impulse responses. ${ }^{11}$ The response of the macroeconomic variables in the standard model confirm the results already obtained in the literature on fiscal policy shocks. ${ }^{12}$ When government consumption expenditure consists only of consumption of goods, then fiscal shocks lead to a substantial negative wealth effect. Households

\footnotetext{
${ }^{11}$ Solid lines with cross markers represent the simulated impulse responses of the indicated variables in the standard model. Solid lines without markers represent the point estimates of the corresponding impulse responses from Figure 5.

${ }^{12}$ See Baxter and King (1993), Ramey and Shapiro (1998), Edelberg, Eichenbaum and Fisher (1999), Burnside, Eichenbaum and Fisher (2004), and Eichenbaum and Fisher (2005).
} 
reduce consumption and increase labor supply, as one can see from panels $\mathrm{H}$ and D, respectively. As a consequence, output increases (panel A), while the real wage decreases (panel G). The increase in output is large enough to allow for an increase in investment (panel F). In fact, the increase in labor supply leads to an increase in the marginal product of capital and this fosters investment. The peak response of investment expenditure is above 25 percent above its preshock level. As already pointed out in Burnside, Eichenbaum and Fisher (2004), the standard neoclassical model can account for the qualitative effects of fiscal shocks. However, it does not do a great job of accounting for the quantitative effects. This is due to the presence of large wealth effects.

Second, I consider the government employment model. In this version, the only fiscal policy variable that reacts to the shock is government hours. Figure 7 3B shows the impulse responses. A shock to government employment is a negative impulse for hours and output in the private sector (panels E and B) and a positive impulse for government output (panel C), as there is a reallocation of labor supply from the private sector to the government sector. Total output decreases on impact (panel A), given the large share of private output in total output. The decrease in total output is quantitatively less strong than the decrease in private output. Given that hours in the private sector decrease, the real wage increases (panel G). Furthermore, since government employment expenditure acts as a transfer, essentially there is no wealth effect associated with the increase in the employment compensation component of government expenditure. Private consumption increases because the real wage increase (panel H). Since private consumption increases and since consumption and leisure are complements, total labor supply decreases as leisure increases (panel D).

Third, I consider the predictions of the modified model. The policy experiment that underlies this version of the model economy is, between the three considered, the one that is more closely related to the policy episodes identified in the data. In the modified model, all four fiscal policy variables respond to the exogenous shock. Figure 8 illustrates the impulse responses obtained with 
the modified model. ${ }^{13}$ Total output increases in a hump-shaped pattern following an exogenous shock and peaks at about 1.32 percent above trend after nine periods (panel A). The response of output in the modified model can reproduce the estimated response to some extent at a qualitative level. The quantitative match, though, is not very strong. Given that the fiscal shock leads to an increase in the goods component of government expenditure, the associated negative wealth effect leads to an increase in labor supply, so that total hours increase (panel D). The peak response on impact is about 0.96 percent above the preshock level. The simulated response of total hours does not match in a particularly successful way the estimated response at a qualitative level, as the estimated response of total hours to a fiscal shock is hump-shaped. The quantitative match is also weak to some extent, as the impact response in the model is smaller than the peak response estimated in the data. Private hours and private output increase also in response to a fiscal shock (panels E and B). The strongest response occurs also on impact, and for both variables it is at about 1 percent above their preshock level. For these variables the match between the simulated and the estimated responses is not eye-catching. The after-tax real wage decreases in a humpshaped way. The largest response is a decrease of about 1.1 percent after six periods (panel G). As for investment, there is a significant increase on impact. Relative to its preshock level, it increases by 3.3 percent (panel F). The simulated response of investment to the fiscal shock matches quite well the corresponding estimated response both at a qualitative and at a quantitative level. Finally, private consumption responds negatively to a fiscal shock (panel $\mathrm{H}$ ). This negative response is generated by the negative wealth effect associated with the increase in government consumption of goods. The simulated response of consumption from the modified model is smaller in absolute value than the corresponding simulated response from the standard model. Allowing for the distinction between goods expenditure and employment expenditure substantially dampens the negative wealth

\footnotetext{
${ }^{13}$ Solid lines with circle markers represent the simulated impulse responses of the indicated variables in the modified model. Solid lines without markers represent the point estimates of the corresponding impulse responses from Figure 5.
} 
effect on consumption associated with fiscal shocks. Remarkably, the impulse response of private consumption from the modified model matches the corresponding estimated impulse response both from a qualitative and a quantitative point of view.

Finally, in Figure 9, I compare the estimated impulse responses of the indicated variables with the corresponding simulated responses from both the standard and the modified model. The standard model performs better than the modified model in accounting for the response of the after-tax real wage to the fiscal policy shock. ${ }^{14}$ For all the other macroeconomic variables considered, the modified model improves upon the standard model at least from a quantitative point of view. The simulated responses from the modified model are closer to their estimated counterparts than the simulated responses from the standard model, and all lie within the 95 percent confidence intervals. These findings indicate that allowing for the distinction between the two main components of government consumption improves the quantitative ability of the neoclassical model in accounting for the effects of fiscal policy shocks.

\section{Conclusions}

In this paper I explicitly considered the distinction between two quantitatively important components of government consumption expenditure: expenditure on goods and expenditure on employment compensation. I have argued that introducing this distinction allows to reproduce with accuracy within a neoclassical model economy the fiscal policy experiment that corresponds more closely to the policy episodes identified in the actual data. It is, hence, possible to assess with improved confidence the ability of the neoclassical model to account for the effects of fiscal policy shocks. I found that introducing the distinction between the two main components of government consumption improves the quantitative performance of a standard neoclassical growth model. The

\footnotetext{
${ }^{14}$ However, the response of the after-tax real wage from the modified model tracks the upper bound of the 95 percent confidence interval.
} 
implied simulated impulse responses match relatively more closely their estimated counterparts than the simulated impulse responses from a neoclassical model economy where government consumption consists exclusively of expenditure on goods.

The main shortcoming of the findings in this paper consist in the inability of the neoclassical model to generate sufficiently large increases in the total number of hours worked and in total output in response to a fiscal shock. This poses a potential challenge to the neoclassical model with government employment used in this paper. A possible solution is to consider an economy with variable factor utilization, along the lines of, for example, Burnside, Eichenbaum and Rebelo (1993), and Bils and Cho (1994). 


\section{Appendix}

\section{A1. Steady-state analysis and log-linearization}

The three first- order conditions for the problem of the household are, one, for $k_{t+1}$ :

(A1) $\frac{C_{t+1}}{C_{t}}=\beta R_{t+1}$,

where $R_{t+1}$ denotes the real rate of return on savings

$$
R_{t+1}=\frac{\left(1-\tau_{t+1}^{k}\right) R_{t+1}^{k}+\delta \tau_{t+1}^{k}+(1-\delta) P_{k, t+1}}{P_{k, t}}
$$

and where $P_{k, t}$ denotes the shadow price, in terms of final goods, of a unit of $k_{t+1}$; two, for $I_{t}$

(A3) $1=P_{k, t} F_{1, t}+\beta \frac{C_{t}}{C_{t+1}} P_{k, t+1} F_{2, t+1}$;

in the nonstochastic steady state given that $F_{1}(\cdot, \cdot)=1$ and that $F_{2}(\cdot, \cdot)=0, P_{k, t}=1$; and, three, for $N_{t}$

$$
\left(1-\tau_{t}^{N}\right) \frac{W_{t}}{C_{t}}=\theta\left(1-n_{t}\right)^{-\mu}
$$

The first-order conditions for private-sector firms are:

(A5) $W_{t}=\alpha\left(\frac{K_{t}}{A_{t} N_{t}^{P}}\right)^{1-\alpha}$,

and

$$
R_{t}^{K}=(1-\alpha)\left(\frac{A_{t} N_{t}^{P}}{K_{t}}\right)^{\alpha}
$$

Steady-state levels of the variables do not carry a subscript. Relevant steady-state prices and ratios are

$$
\begin{aligned}
& R=\frac{1+a}{\beta}, \quad R^{k}=\frac{R-\delta \tau^{k}-(1-\delta)}{1-\tau^{k}}, \quad \frac{K}{Y^{P}}=\frac{1-\alpha}{R^{K}}, \\
& \frac{I}{K}=a+\delta, \quad \frac{I}{Y}=\frac{I}{K} \frac{K}{Y^{P}} \frac{Y^{P}}{Y}, \quad \frac{C}{Y}=1-\frac{I}{Y}-\frac{G+W N^{G}}{Y} .
\end{aligned}
$$


"Hat" variables denote log-deviations from steady-state levels. The complete set of log-linearized equations is as follows: the log-linear version of the consumption Euler equation is:

$$
\hat{C}_{t+1}-\hat{C}_{t}=\hat{R}_{t+1}
$$

As for equation (A2):

$$
\hat{R}_{t+1}=\frac{\left(1-\tau^{k}\right) R^{k}}{R} \hat{R}_{t+1}^{k}+\frac{\tau^{k}\left(\delta-R^{k}\right)}{R} \hat{\tau}_{t+1}^{k}+\frac{1-\delta}{R} \hat{P}_{k, t+1}-\hat{P}_{k, t} .
$$

Next, as in Christiano et al. (2001), the first- order condition (A3) on $I_{t}$ can be linearized as follows:

$$
\hat{P}_{k, t}=s\left[\hat{I}_{t}-\hat{I}_{t-1}-\frac{1}{R}\left(\hat{I}_{t+1}-\hat{I}_{t}\right)\right]
$$

As for the first-order condition for labor supply:

$$
\hat{W}_{t}-\hat{C}_{t}-\frac{\tau^{n}}{1-\tau^{n}} \hat{\tau}_{t}^{n}=\mu \frac{n}{1-n} \hat{n}_{t}
$$

The log-linear versions of the two first- order conditions for private-sector firms are:

$$
\hat{W}_{t}=\alpha\left(\hat{K}_{t}-\hat{N}_{t}^{P}\right)
$$

and:

$$
\hat{R}_{t}^{K}=(1-\alpha)\left(\hat{N}_{t}^{P}-\hat{K}_{t}\right)^{\alpha}
$$

Next, the law of motion for capital:

$$
\hat{K}_{t+1}=\frac{1-\delta}{1+a} \hat{K}_{t}+\frac{a+\delta}{1+a} \hat{I}_{t}
$$

the production function of private-sector firms:

$$
\hat{Y}_{t}^{P}=\alpha \hat{N}_{t}^{P}+(1-\alpha) \hat{K}_{t}
$$

the production function for the government:

$$
\hat{Y}_{t}^{P}=\gamma \hat{N}_{t}^{G}+(1-\gamma) \hat{G}_{t}
$$


the definition of total output:

$$
\hat{Y}_{t}=\frac{Y^{P}}{Y} \hat{y}_{t}^{P}+\frac{Y^{G}}{Y} \hat{Y}_{t}^{G}
$$

the labor-market clearing condition:

$$
\hat{n}_{t}=\frac{N^{P}}{n} \hat{N}_{t}^{P}+\frac{N^{G}}{n} \hat{N}_{t}^{G},
$$

and the aggregate resource constraint:

$$
\hat{Y}_{t}=\frac{C}{Y} \hat{C}_{t}+\frac{I}{Y} \hat{I}_{t}+\frac{G}{Y} \hat{G}_{t}
$$

\section{A2. Data}

This appendix describes and lists the data used in the empirical analysis in Section 2. I obtained data from four different sources: Bureau of Economic Analysis, Bureau of Labor Statistics, DRI Economics Database, and U.S. Census Bureau.

\section{Bureau of Economic Analysis}

Data are from the NIPA tables.

They are available at http://www.bea.gov/bea/dn/nipaweb. Real chained-dollar NIPA series are usually not additive. When I add together two or more chain weighted series I adjust their sum using the method of Whelan (2000). I deflated nominal series using the corresponding chain-type price indexes available in Section 7 of the NIPA tables. The series that I used are as follows:

Total output: Gross domestic output, table 1.2, line 1;

Private consumption: Consumption of nondurable goods plus consumption of services, table 1.2, lines 4 and 5 ;

Investment: Consumption of durable goods plus gross private domestic investment, table 1.2, lines 3 and 6 plus government gross investment;

Government purchases: Government consumption expenditures and gross investment, table 1.2, line 20 ; 
Government consumption: Government consumption expenditures on goods and services, table 3.7, lines 4, 15, and 28, minus compensation of general government employees, table 3.7, line 38;

Government gross investment: table 3.7, lines 11, 24 and 35;

Defense spending: National Defense spending, table 1.2, line 22;

Defense compensation: National defense compensation of general government employees, table 3.7, line 8;

Private output: Gross domestic nonfarm business product, table 1.8, line 3;

Government output: Gross domestic product of general government, table 1.8, line 10;

Government hours: Hours worked by full-time and part-time employees in the general government sector, SIC classification, table 6.9, line 21. This series is available only at annual frequency. I obtained a quarterly series using the interpolation technique of Chow and Lin (1971) and employing compensation of general government employees and government employment as quarterly interpolators.

\section{Bureau of Labor Statistics}

Data are available at http://www.bls.gov/data.

Population: Labor Force Statistics from the Current Population Survey, series ID: LFU800000000 (also DRI Economics Database, code: P16);

Government employment: Government civilian employment plus military employment;

Government civilian employment: Current Employment Statistics, series ID: EES90000001 (also DRI Economics Database, code: LPGOV);

Military employment: Labor Force Statistics from the Current Population Survey, Armed forces population resident and overseas, series ID: LFU900000, available 1948-1993;

Defense employment: Defense civilian employment plus military employment;

Defense civilian employment: Current Employment Statistics, Department of Defense, all employees, 
series ID: EEU91911001;

Private hours: Nonfarm business hours index, 1992=100, series ID: PRS85006033 (also DRI Economics Database, hours of all persons, nonfarm business sector, code: LBMNU);

Real wage: Nonfarm business real hourly compensation index, $1992=100$, series ID: PRS85006153 (also DRI Economics Database, real compensation per hour, nonfarm business, code: LBCPU7);

\section{DRI Economics Database}

Total hours: Employee-hours in nonagricultural establishments, code: LPMHU.

\section{U.S. Census Bureau}

Data are available at http://eire.census.gov/popest/archives/national/nation1.php.

Military employment: Population estimates, resident population plus armed forces overseas minus civilian population, available 1980-2000. 


\section{References}

Aiyagari, S.R., L.J. Christiano and M. Eichenbaum, 1992. The output, employment and interest rate effects of government consumption. Journal of Monetary Economics 39, 73-86.

Alesina, A., S. Ardagna, R. Perotti and F. Schiantarelli, 2002. Fiscal policy, profits and investment. American Economic Review 92, 571-589.

Anderson, G. and G. Moore, 1985. A linear algebraic procedure for solving linear perfect foresight models. Economics Letters 17, 247-252.

Ardagna, S., 2001. Fiscal policy composition, public debt and economic activity. Public Choice 109, 301-325.

Basu, S. and M. Kimball, 2004. Investment planning costs and the effects of fiscal and monetary policy. Mimeo, University of Michigan.

Baxter, M. and R.G. King, 1993. Fiscal policy in general equilibrium. American Economic Review 83, 315-334.

Bils, M. and J. Cho, 1994. Cyclical factor utilization. Journal of Monetary Economics 33, 319-354.

Braun, R.A., 1994. Tax disturbances and real economic activity in the postwar United States. Journal of Monetary Economics 33, 441-462.

Blanchard, O.J. and R. Perotti, 2002. An empirical characterization of the dynamic effects of changes in government spending and taxes on output. Quarterly Journal of Economics 117, $1329-1368$.

Burnside, C., M. Eichenbaum and J.D.M. Fisher, 2004. Fiscal shocks and their consequences, Journal of Economic Theory 115, 89-117.

Burnside, C., M. Eichenbaum and S. Rebelo, 1993. Labor hoarding and the business cycle. Journal of Political Economy 101, 245-273. 
Chow, G.C. and A. Lin, 1971. Best linear unbiased interpolation, distribution and extrapolation of time series by related series. Review of Economics and Statistics 53, 372-375.

Campbell, J.Y., 1994. Inspecting the mechanism: An analytical approach to the stochastic growth model. Journal of Monetary Economics 33, 463-506.

Christiano, L.J. and M. Eichenbaum, 1992. Current Real-Business-Cycle theories and aggregate labor-market fluctuations. American Economic Review 82, 430-450.

Christiano, L.J., M. Eichenbaum and C.L. Evans, 2005. Nominal rigidities and the dynamic effects of a shock to monetary policy. Journal of Political Economy 113, 1-45.

Dotsey, M., 1994. Some unpleasant supply side arithmetic. Journal of Monetary Economics 33, $507-524$.

Edelberg, W., M. Eichenbaum and J.D.M. Fisher, 1999. Understanding the effects of a shock to government purchases. Review of Economic Dynamics 2, 166-206.

Eichenbaum, M. and J.D.M. Fisher, 2005. Fiscal policy in the aftermath of 9/11. Journal of Money, Credit and Banking 37, 1-22.

Fatás, A. and I. Mihov, 2001. The effects of fiscal policy on consumption and employment: Theory and evidence. CEPR Discussion Paper no. 2760.

Finn, M.G., 1998. Cyclical effects of government's employment and goods purchases. International Economic Review 39, 635-657.

Francis, N.R. and V.A. Ramey, 2005. A century of work and leisure. Mimeo, UCSD.

Galí. J., J.D. López-Salido and J. Vallés, 2005. Understanding the effects of government spending on consumption. Journal of the European Economic Association, forthcoming.

Jones, J.B., 2002. Has fiscal policy helped stabilize the postwar U.S. economy? Journal of Monetary Economics 49, 709-746.

McGrattan, E.R., 1994. The macroeconomic effects of distortionary taxation. Journal of Mon- 
etary Economics 33, 573-601.

McGrattan, E.R., Ohanian, L.E., 2003. Does neoclassical theory account for the effects of big fiscal shocks? Evidence from World War II. Federal Reserve Bank of Minneapolis Staff Report no. 315.

Mountford, A. and H. Uhlig, 2002. What are the effects of fiscal policy shocks? CEPR Discussion Paper no. 3338.

Ohanian, L.E., 1997. The macroeconomic effects of war finance in the United States: World War II and the Korean war. American Economic Review 87, 23-40.

Perotti, R., 2005. Estimating the effects of fiscal policy in OECD countries. CEPR Discussion Paper no. 4842.

Ramey, V.A. and M. Shapiro, 1998. Costly capital reallocation and the effects of government spending. Carnegie-Rochester Conference Series on Public Policy 48, 145-194.

Rotemberg, J.J. and M. Woodford, 1992. Oligopolistic pricing and the effects of aggregate demand on economic activity. Journal of Political Economy 100, 1153-1207.

Whelan, K., 2000. A guide to the use of chain aggregated NIPA data. Finance and Economics Discussion Paper no. 2000-35, Federal Reserve Board. 
Figure 1: Defense expenditure and Ramey-Shapiro Dates.

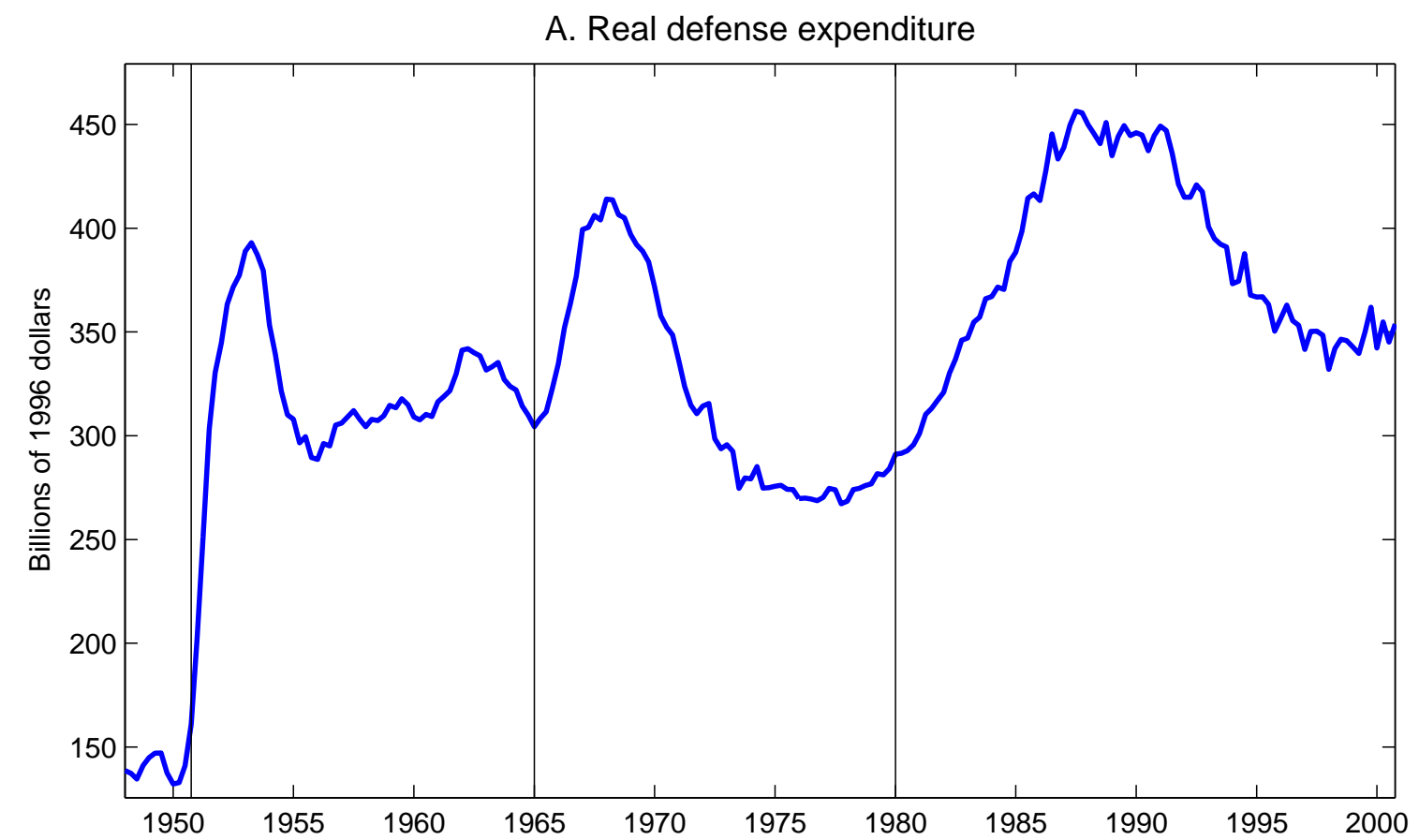

B. Share of defense expenditure in GDP

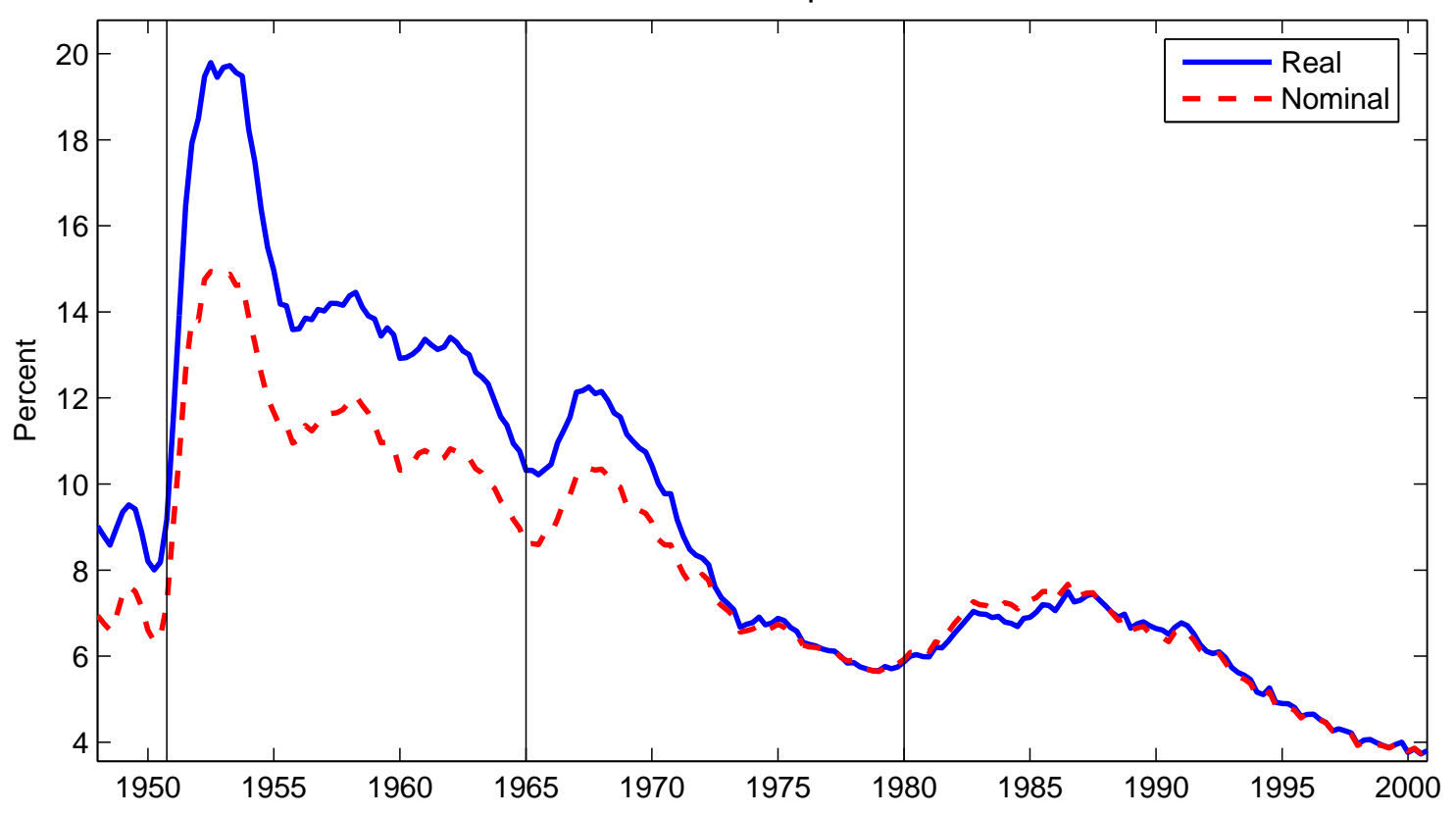


Figure 2: Fiscal policy variables and RAmey-Shapiro Dates.

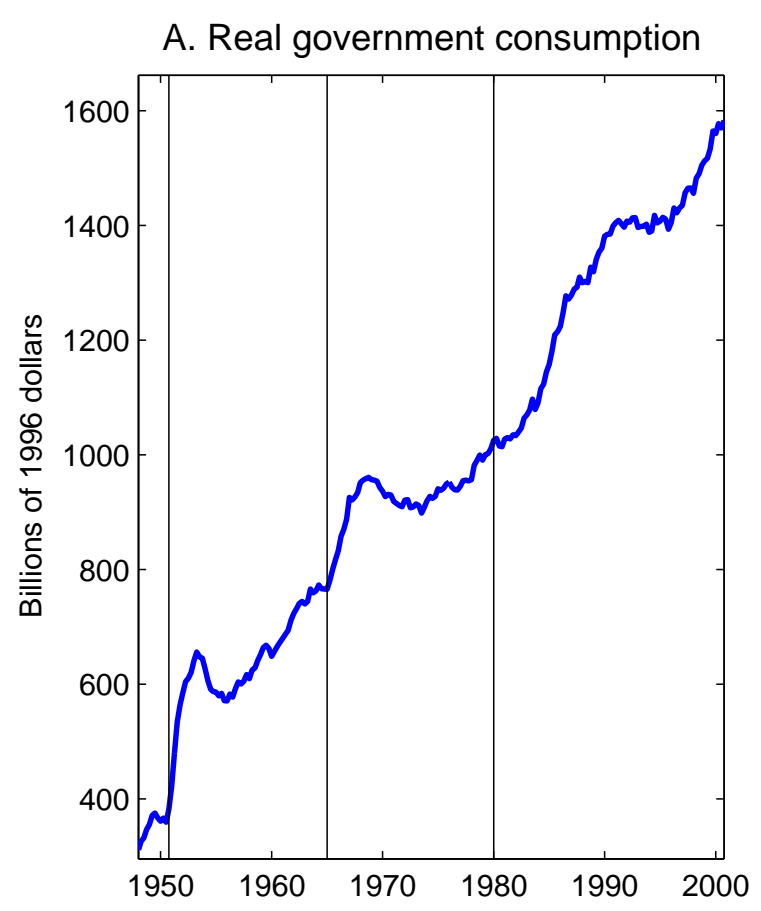

B. Share of government consumption in GDP
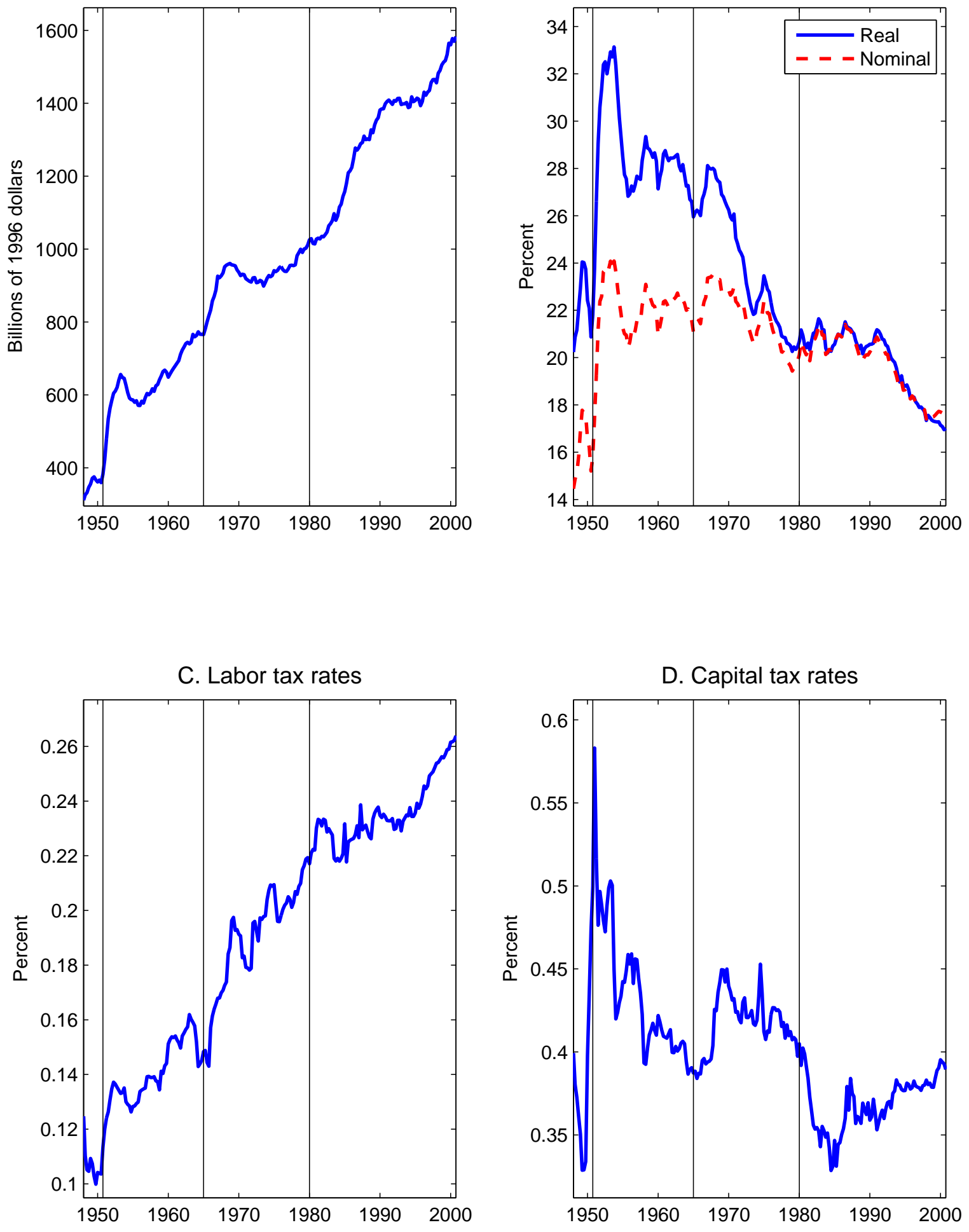
Figure 3: Measures of government employment and Ramey-Shapiro dates.
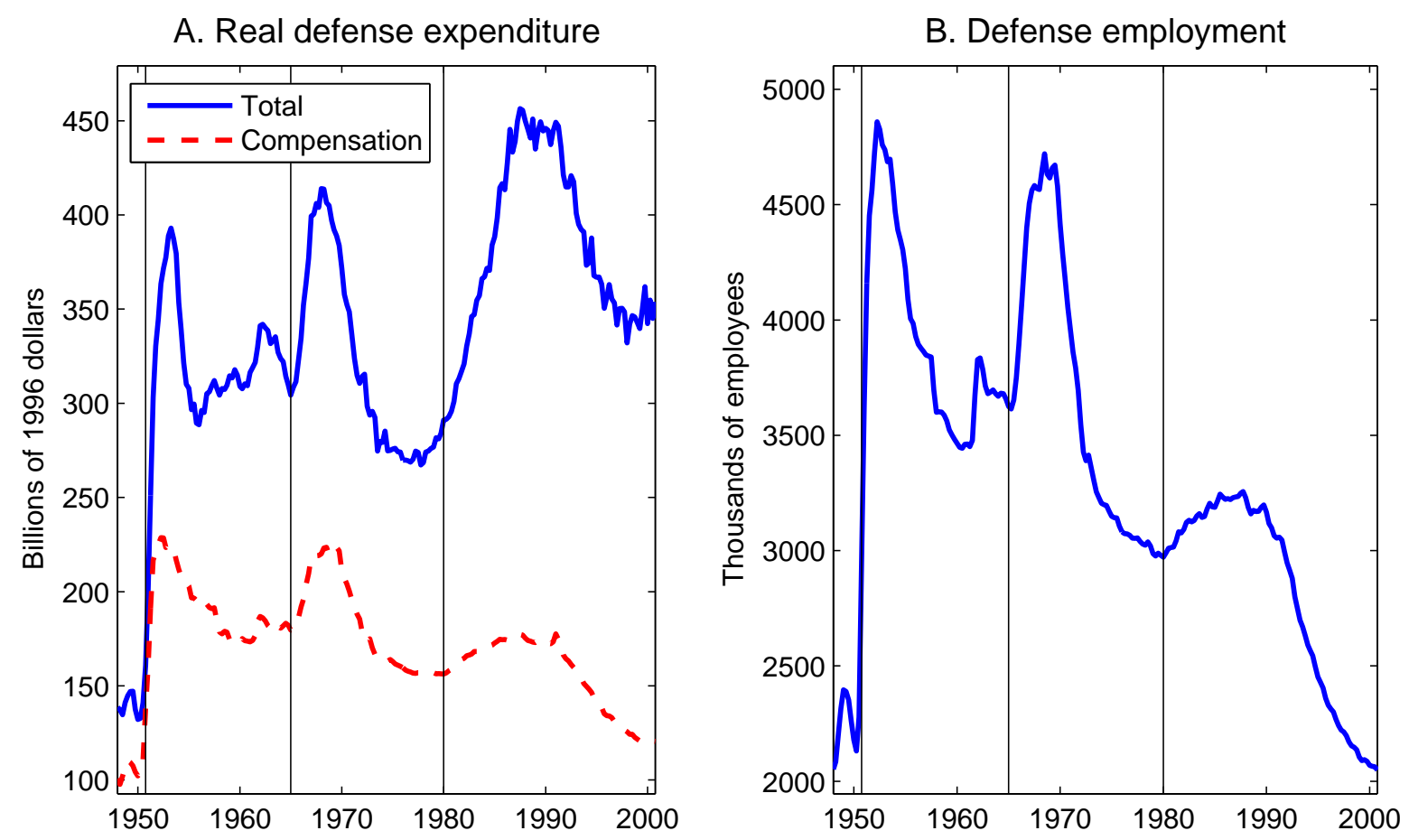

C. Government employment / population

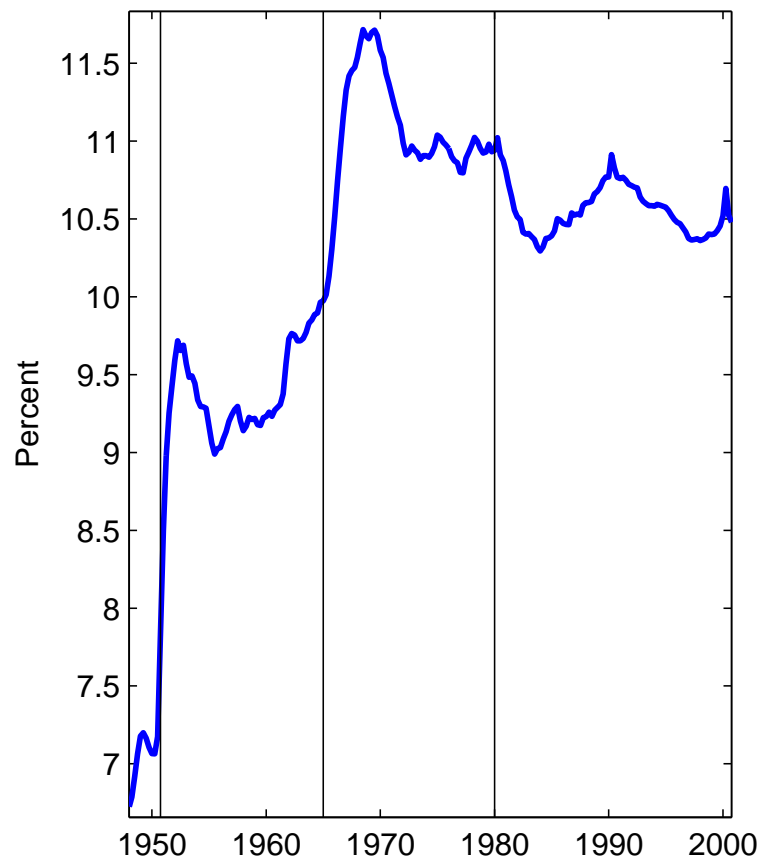

D. Government hours per capita

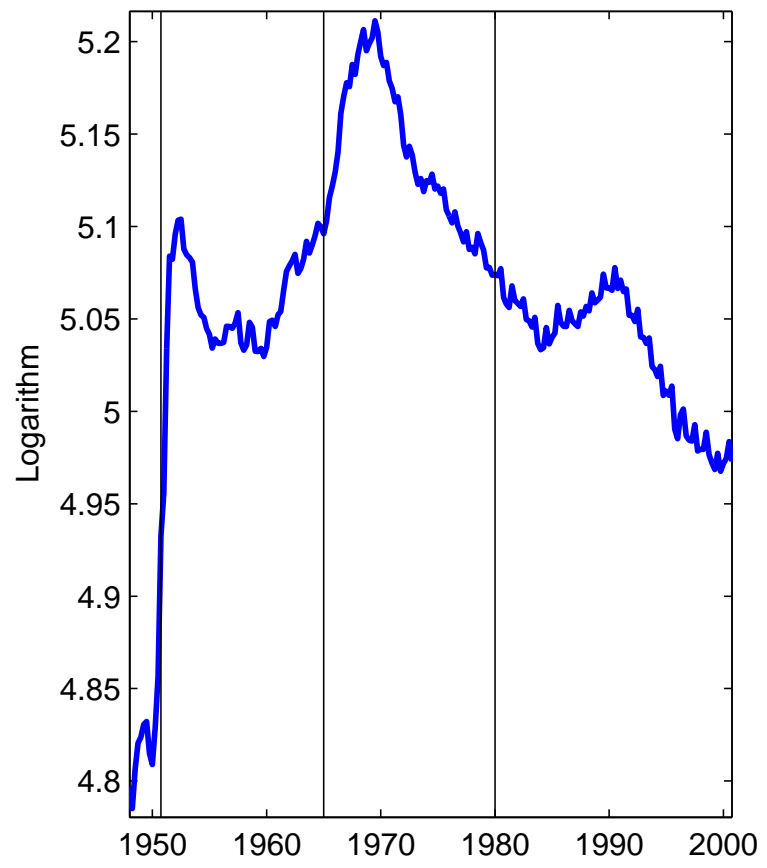


Figure 4: Estimated Responses to the onset of a RAMEY-Shapiro EPisode.

A. Government consumption of goods
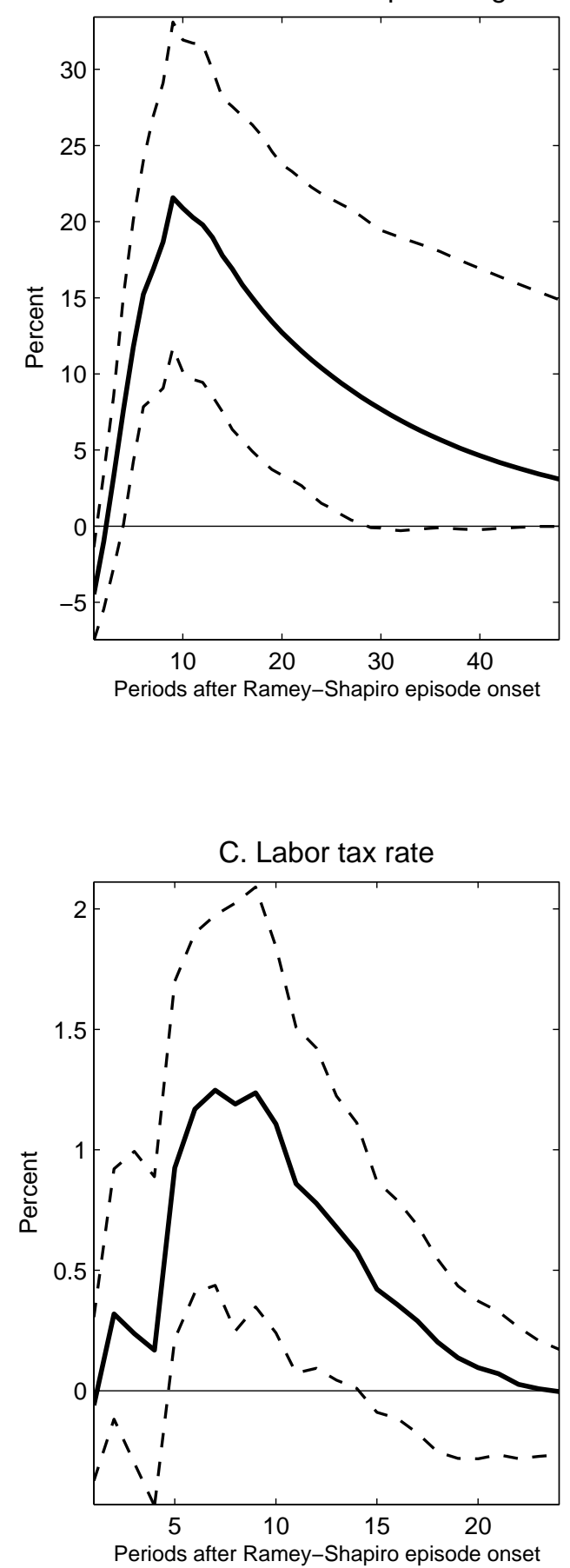

B. Government hours

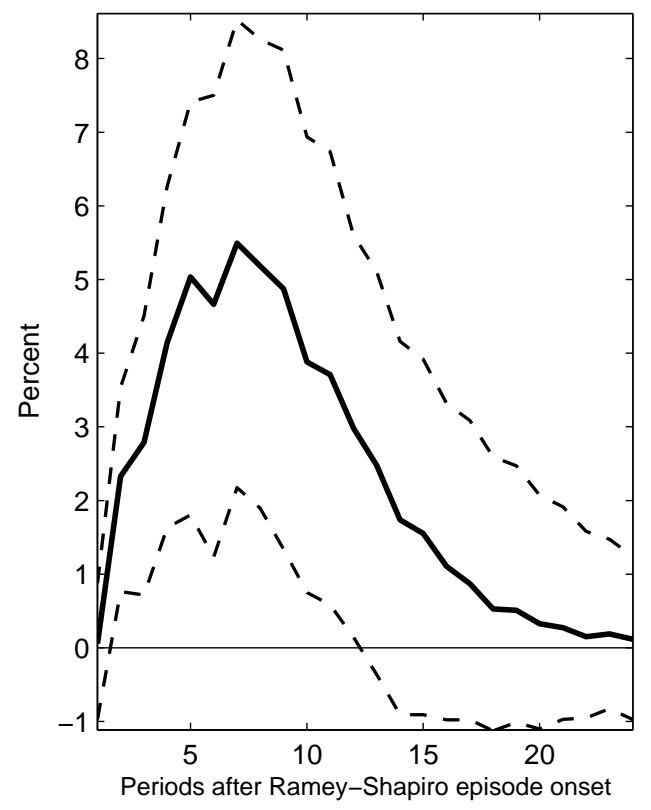

D. Capital tax rate

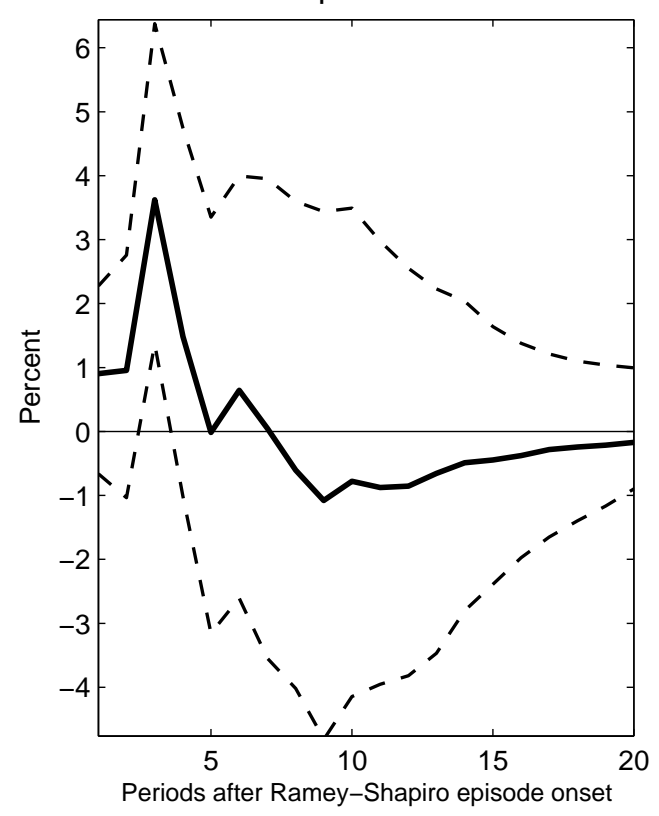

Note: Solid lines represent point estimates. Dashed lines delimit a 95 percent confidence interval. 
Figure 5: Estimated Responses to the onset of a Ramey-Shapiro ePisode.

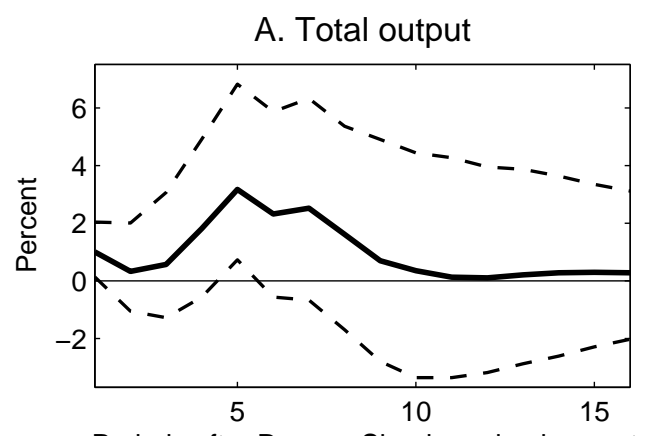

Periods after Ramey-Shapiro episode onset C. Government output

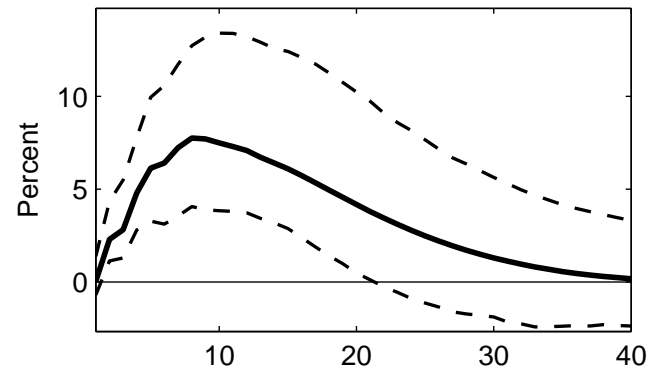

Periods after Ramey-Shapiro episode onset

E. Private hours

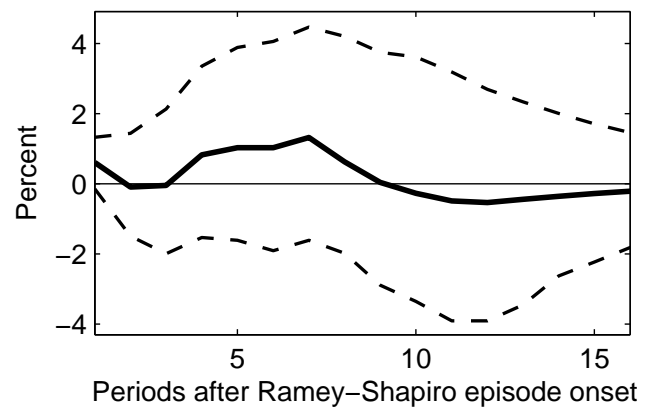

G. After-tax compensation

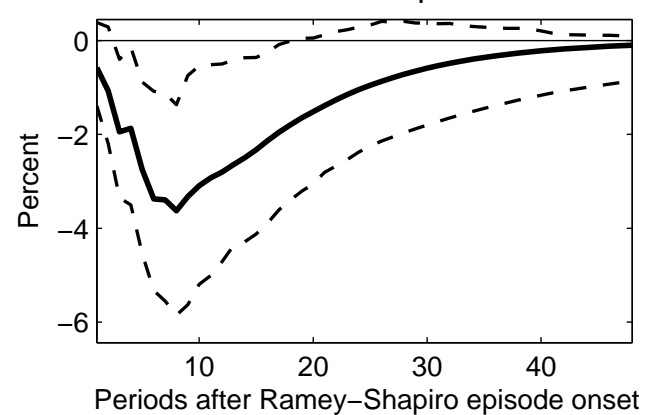

B. Private output

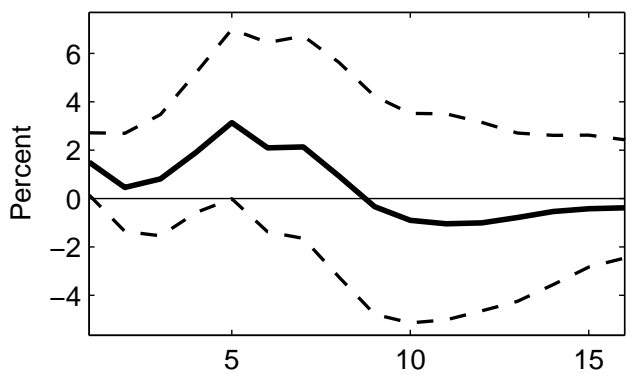

Periods after Ramey-Shapiro episode onset

D. Total hours

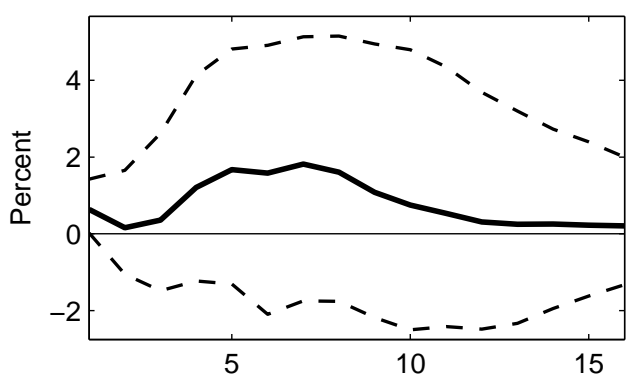

Periods after Ramey-Shapiro episode onset F. Investment

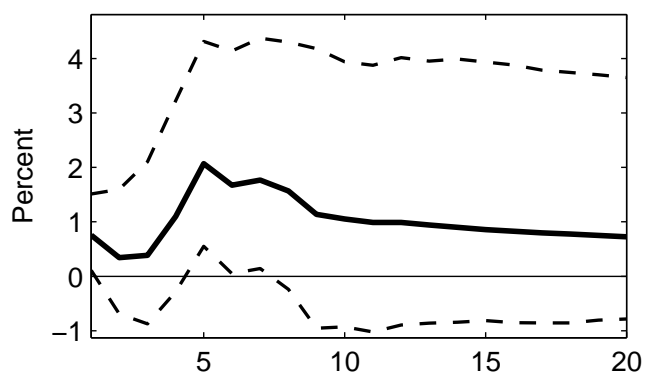

Periods after Ramey-Shapiro episode onset H. Private consumption

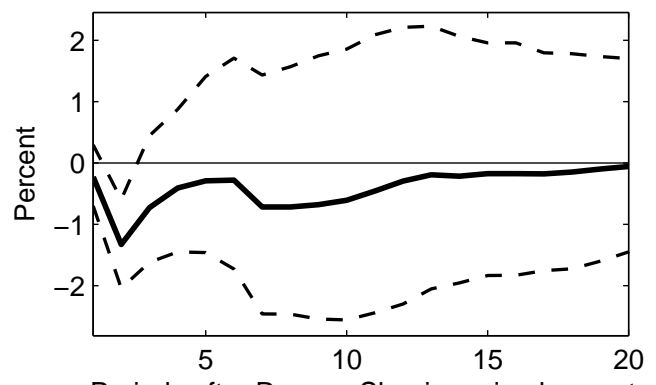

Periods after Ramey-Shapiro episode onset

Note: Solid lines represent point estimates. Dashed lines delimit a 95 percent confidence interval. 
Figure 6: Simulated Responses in the standard model.

A. Total output

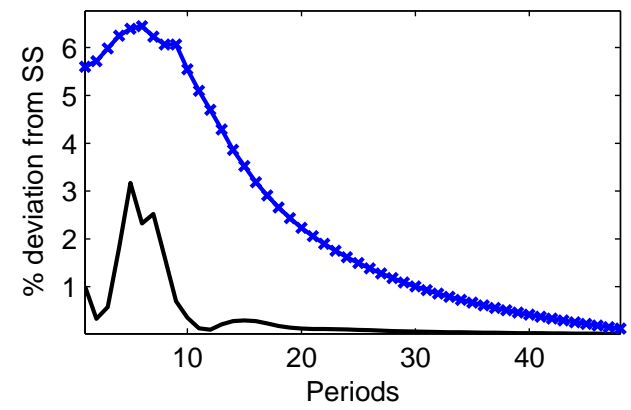

C. Government output

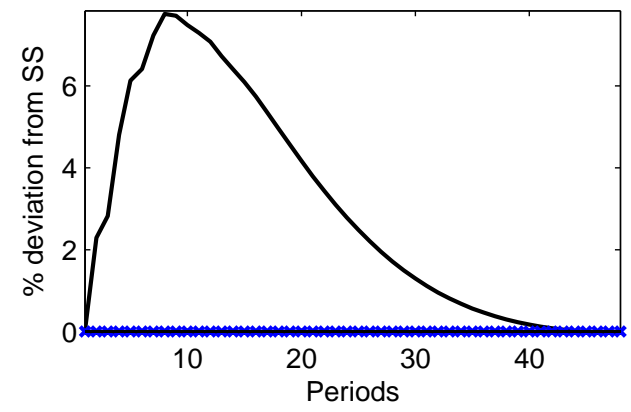

E. Private hours

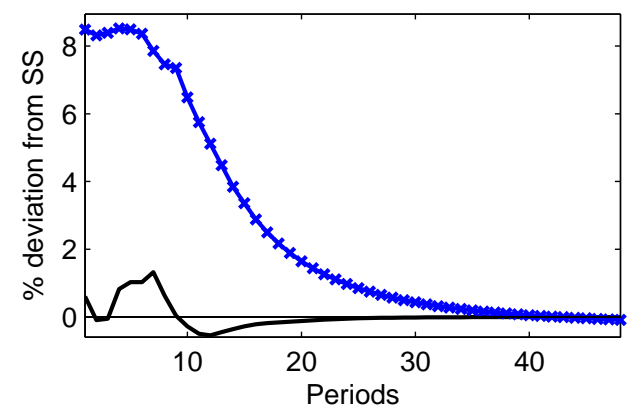

G. After-tax real wage

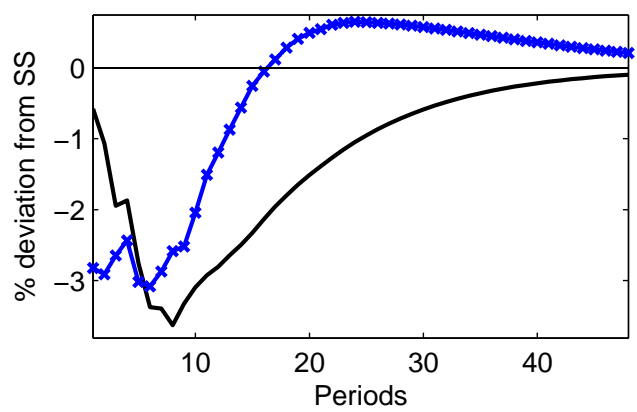

B. Private output

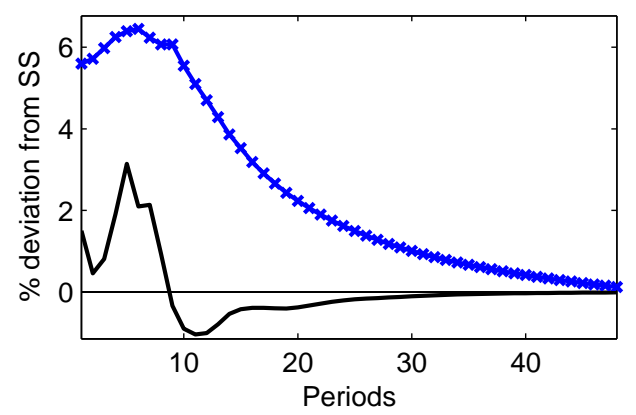

D. Total hours

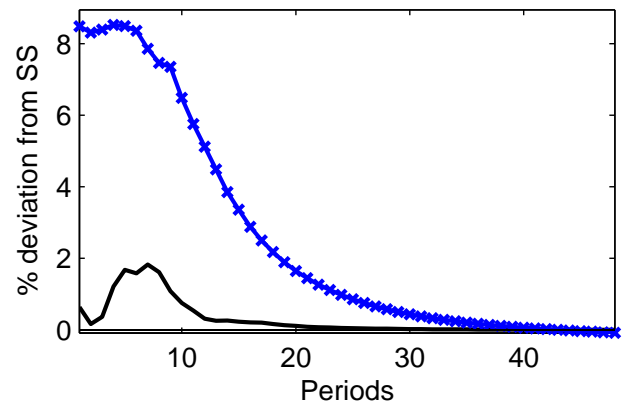

F. Investment

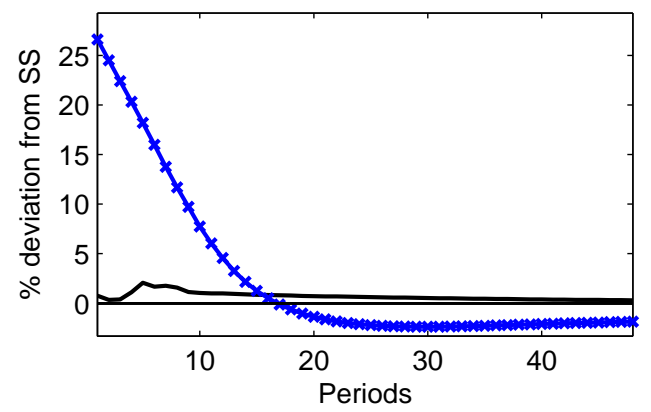

H. Private consumption

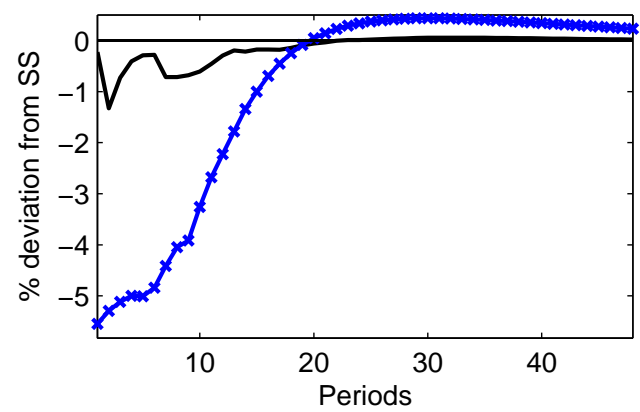

Note: Solid lines with cross markers represent the simulated impulse responses of the indicated variables from the standard model. Solid lines without markers represent the point estimates of the corresponding impulse responses from Figure 5. 
Figure 7: Simulated Responses in the government employment Model.
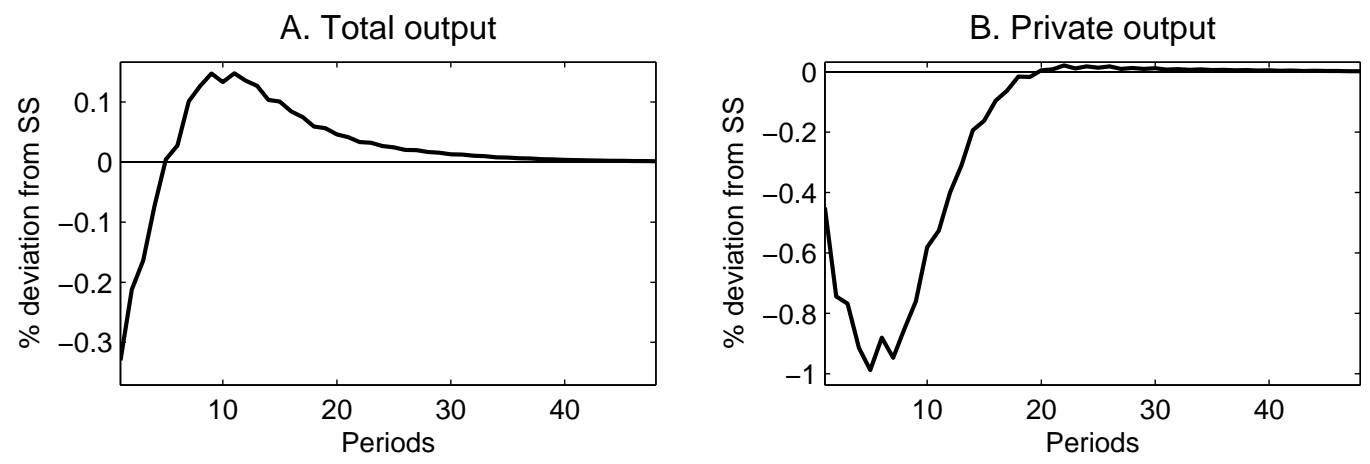

C. Government output

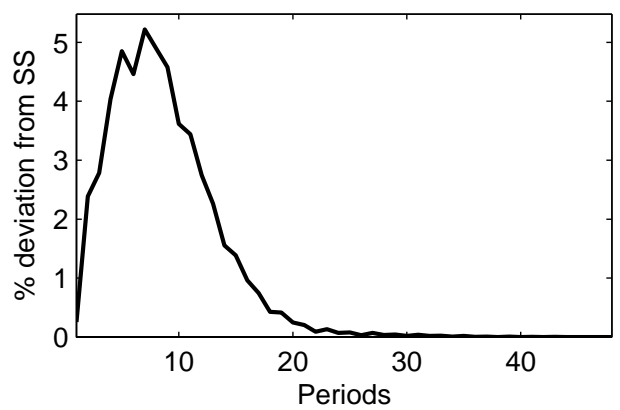

D. Total hours

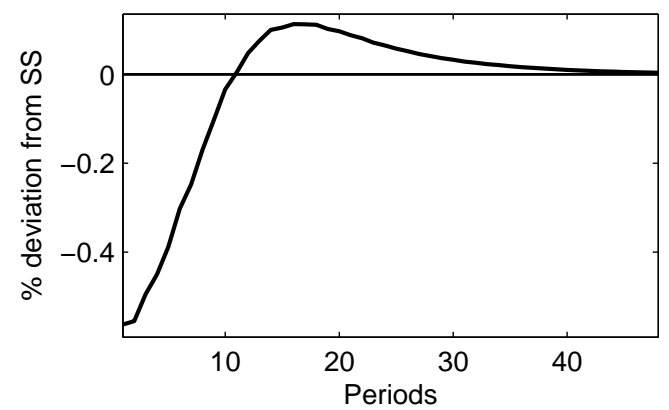

E. Private hours

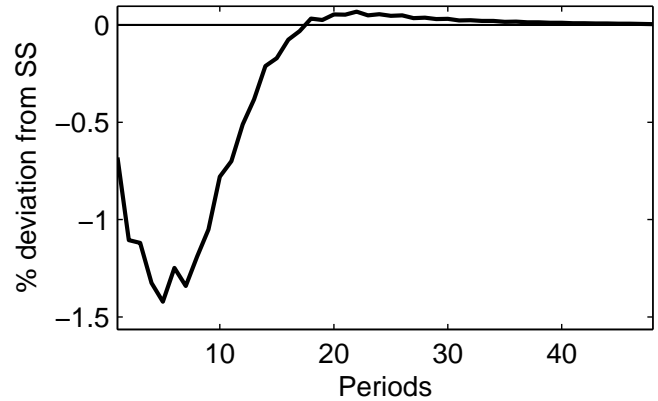

F. Investment

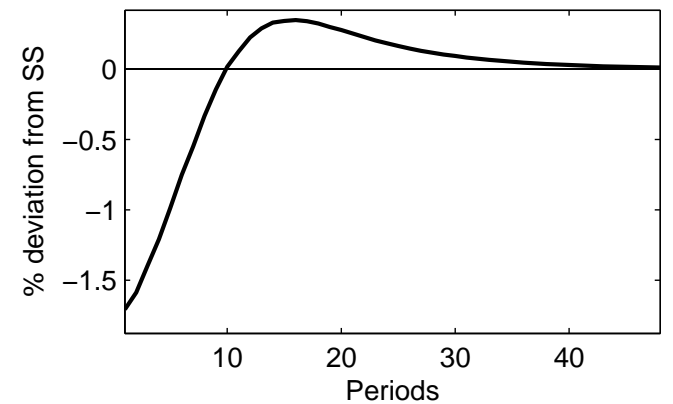

G. After-tax real wage

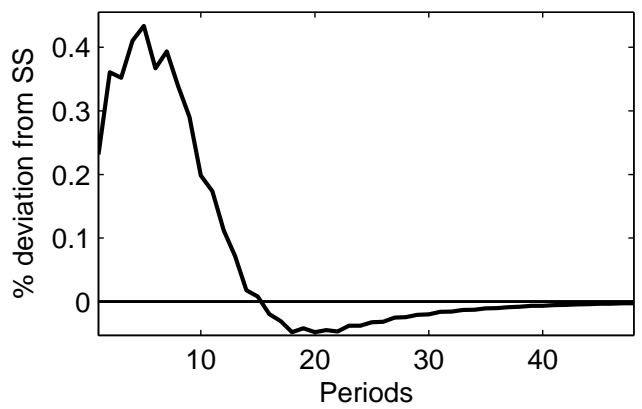

H. Private consumption

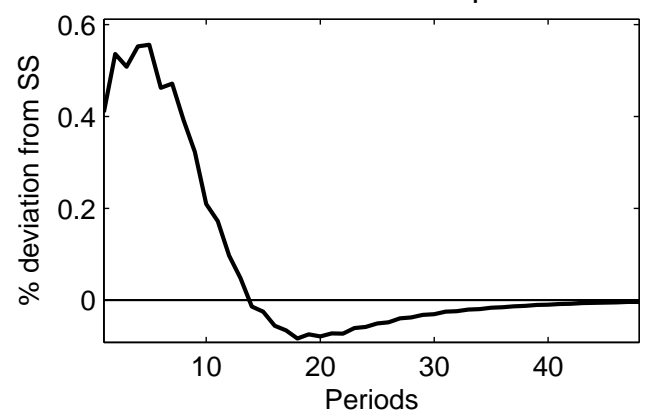

Note: Solid lines represent the response of the indicated variable from the government employment model. 
Figure 8: Simulated Responses of VARIABles in the MOdified Model.

A. Total output

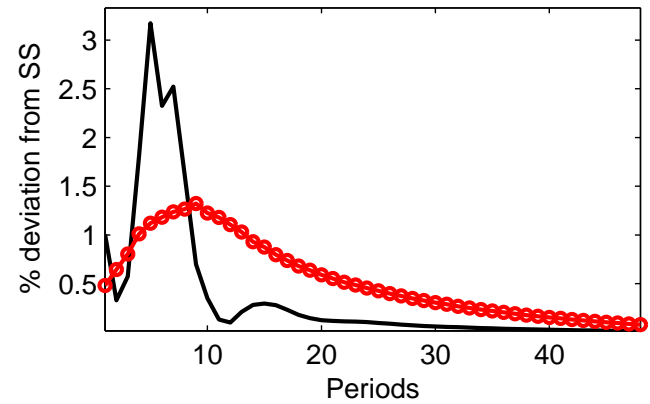

C. Government output

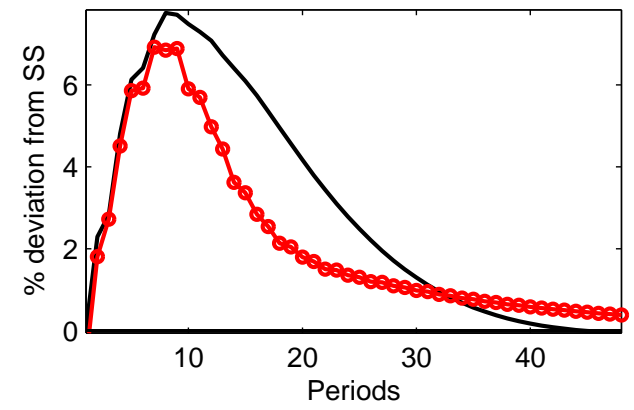

E. Private hours

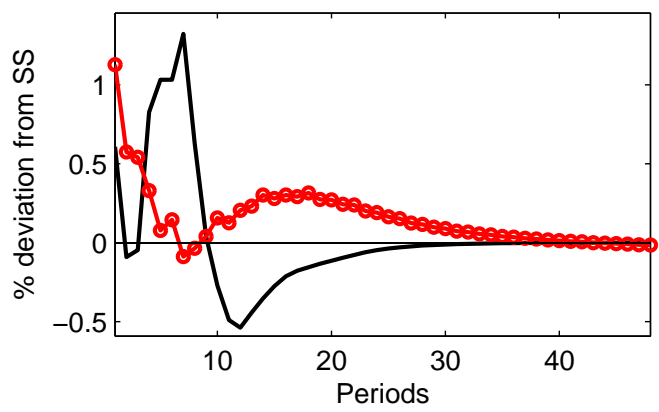

G. After-tax real wage

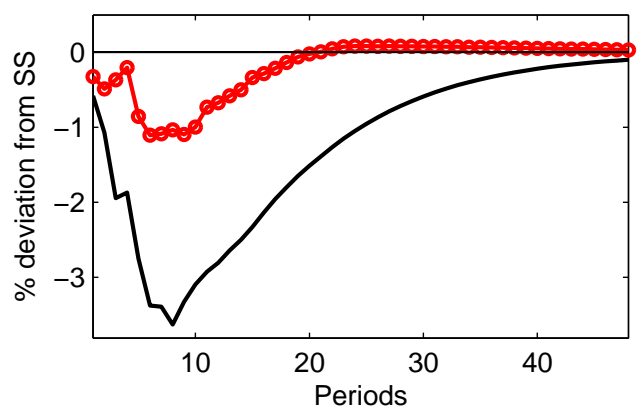

B. Private output

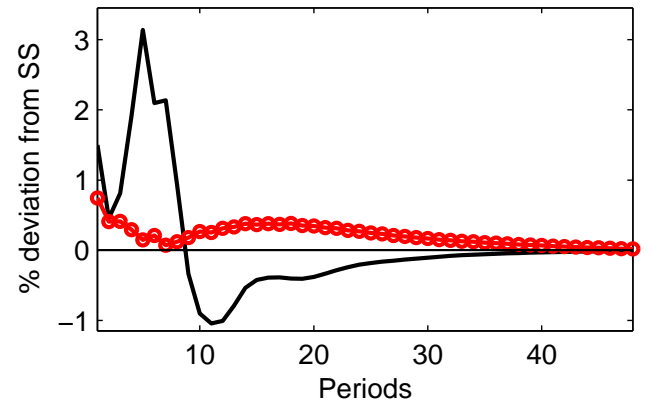

D. Total hours

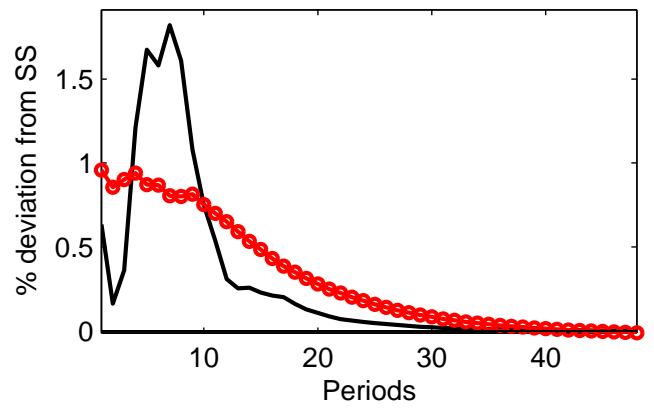

F. Investment

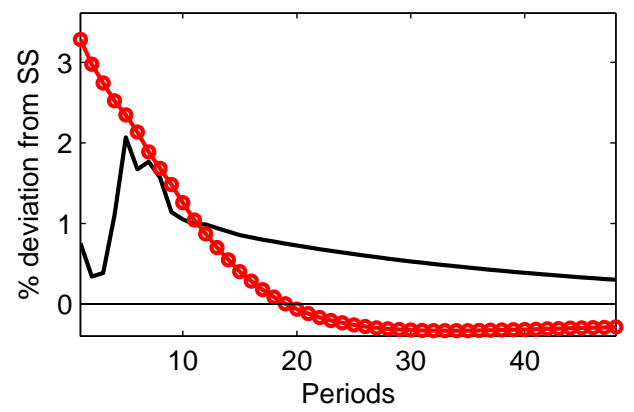

H. Private consumption

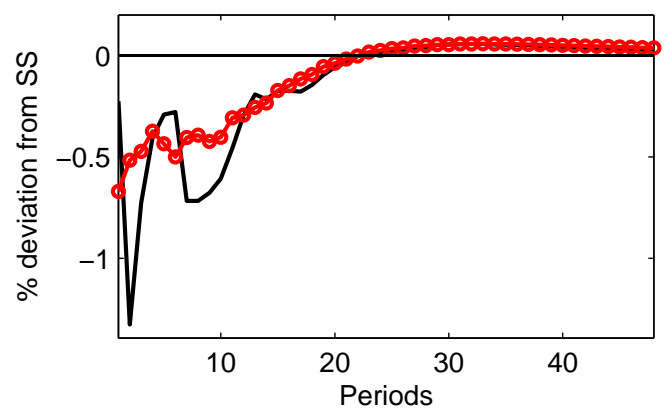

Note: Solid lines with circle markers represent the simulated impulse responses of the indicated variables from the modified model. Solid lines without markers represent the point estimates of the corresponding impulse responses from Figure 5. 

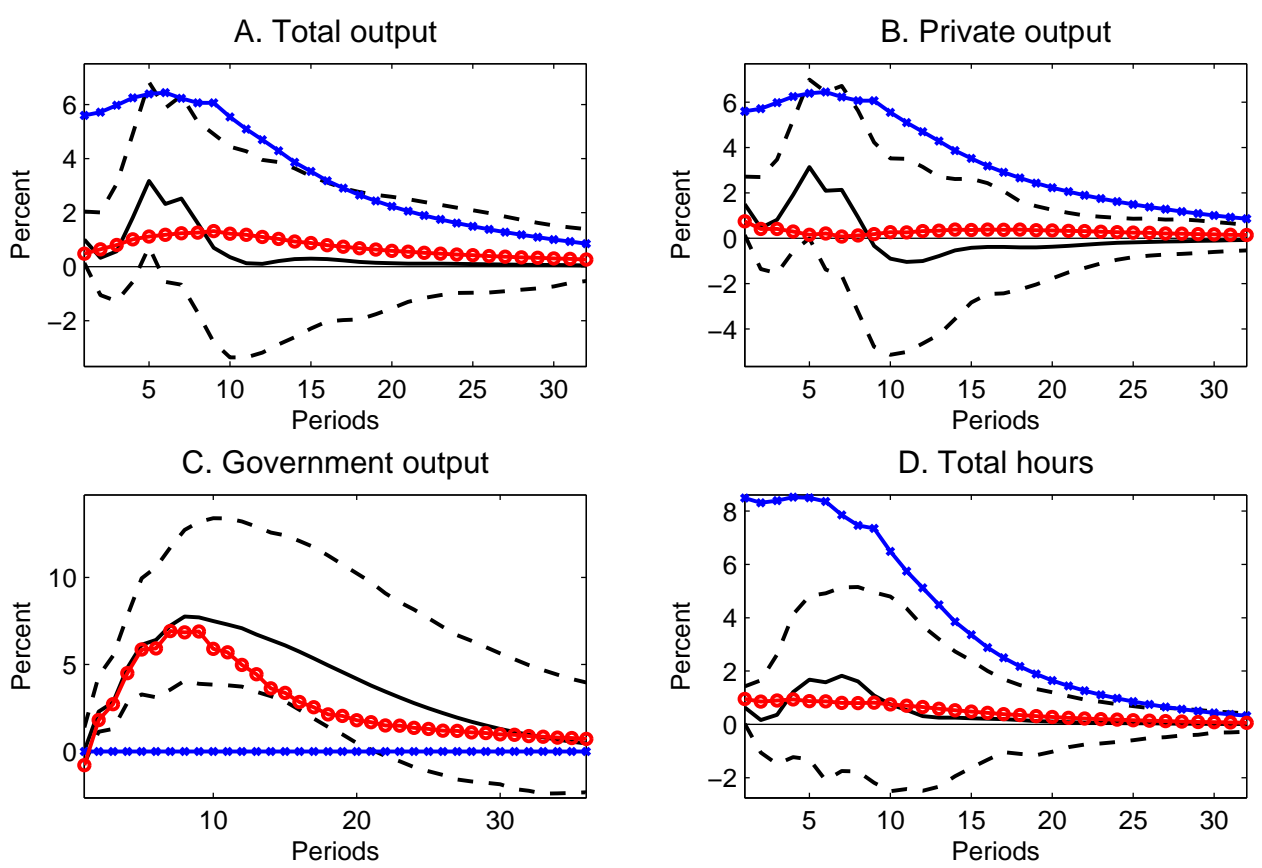

E. Private hours

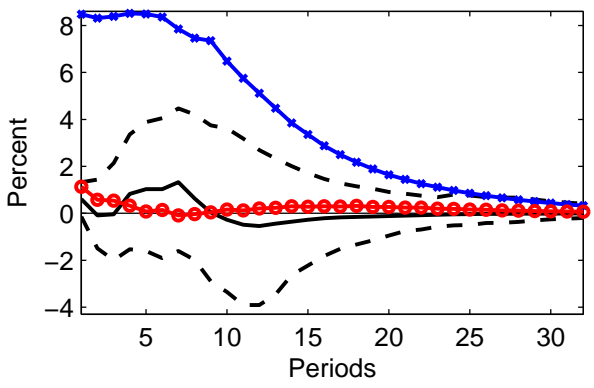

F. Investment

G. After-tax real wage
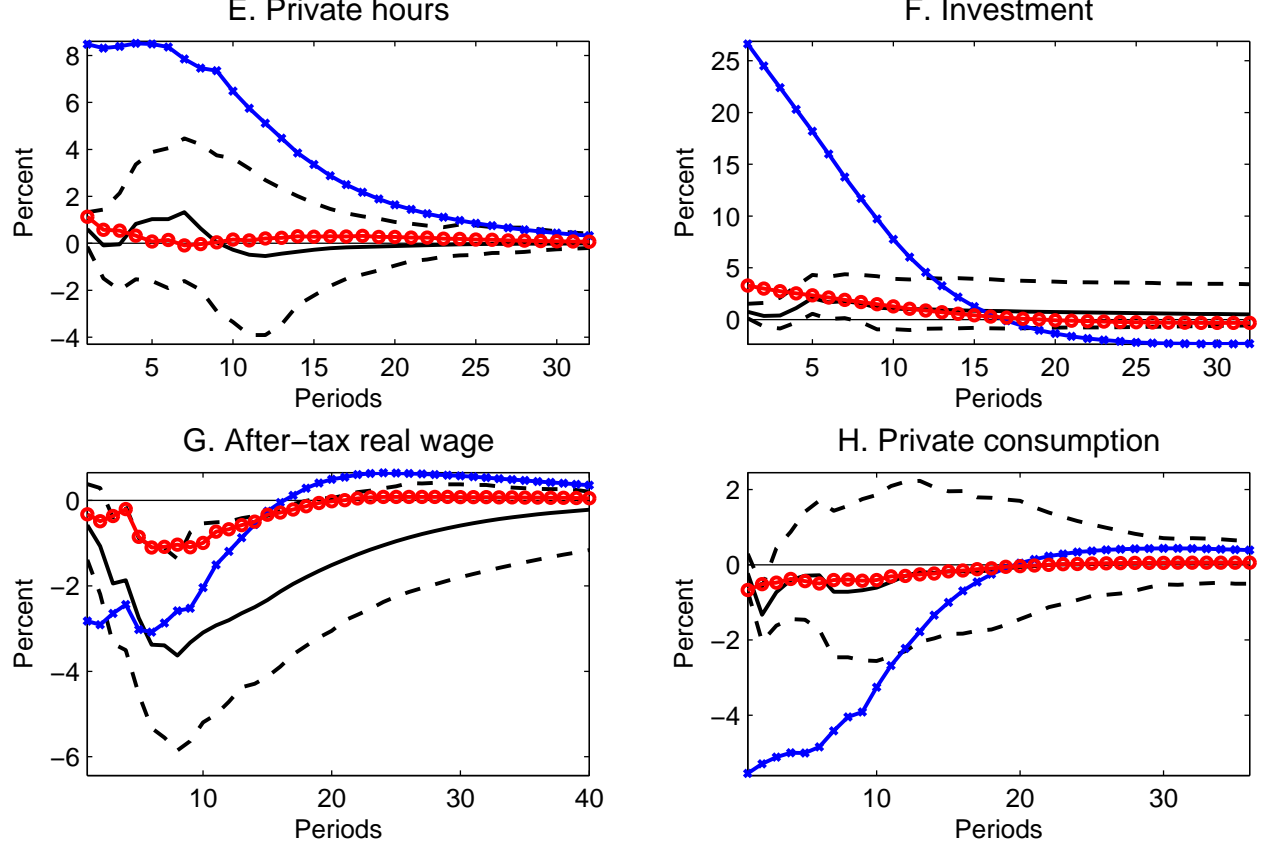

H. Private consumption

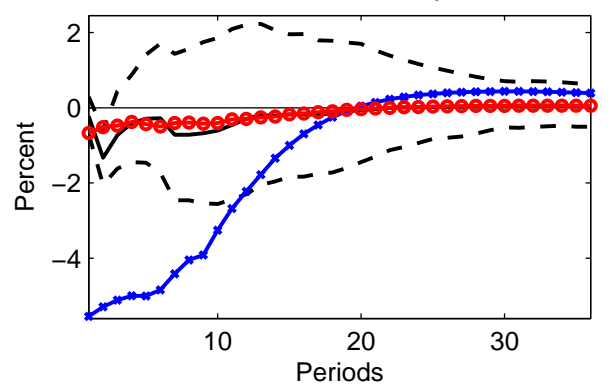

Note: Solid lines represent point estimates from Figure 5 for the response of the indicated variable. Dashed lines delimit a 95 percent confidence interval. Solid lines with cross markers represent the response of the indicated variable from the standard model. Solid lines with circle markers represent the response of the indicated variable from the modified model. 